\title{
Depolymerization and conversion of lignin to value-added bioproducts by microbial and enzymatic catalysis
}

Caihong Weng ${ }^{1,2}$, Xiaowei Peng ${ }^{1,2}$ and Yejun $\operatorname{Han}^{1,2^{*}}$ (1)

\begin{abstract}
Lignin, the most abundant renewable aromatic compound in nature, is an excellent feedstock for value-added bioproducts manufacturing; while the intrinsic heterogeneity and recalcitrance of which hindered the efficient lignin biorefinery and utilization. Compared with chemical processing, bioprocessing with microbial and enzymatic catalysis is a clean and efficient method for lignin depolymerization and conversion. Generally, lignin bioprocessing involves lignin decomposition to lignin-based aromatics via extracellular microbial enzymes and further converted to value-added bioproducts through microbial metabolism. In the review, the most recent advances in degradation and conversion of lignin to value-added bioproducts catalyzed by microbes and enzymes were summarized. The lignin-degrading microorganisms of white-rot fungi, brown-rot fungi, soft-rot fungi, and bacteria under aerobic and anaerobic conditions were comparatively analyzed. The catalytic metabolism of the microbial lignin-degrading enzymes of laccase, lignin peroxidase, manganese peroxidase, biphenyl bond cleavage enzyme, versatile peroxidase, and $\beta$-etherize was discussed. The microbial metabolic process of H-lignin, G-lignin, S-lignin based derivatives, protocatechuic acid, and catechol was reviewed. Lignin was depolymerized to lignin-derived aromatic compounds by the secreted enzymes of fungi and bacteria, and the aromatics were converted to value-added compounds through microbial catalysis and metabolic engineering. The review also proposes new insights for future work to overcome the recalcitrance of lignin and convert it to value-added bioproducts by microbial and enzymatic catalysis.
\end{abstract}

Keywords: Lignin, Depolymerization, Enzymatic degradation, Lignin-derived aromatics, Metabolic pathways, Valueadded bioproducts, Biosynthesis

\section{Background}

Converting the renewable biomass to chemicals and fuels is an attractive and green method for the sustainable environment development. Lignocellulose, the most abundant renewable resource in nature, is mainly composed of cellulose, hemicellulose, and lignin [1]. Cellulose and hemicellulose can be degraded into monosaccharides by enzymatic hydrolysis [2-5] and fermented to various

\footnotetext{
*Correspondence: yjhan@ipe.ac.cn

${ }^{1}$ National Key Laboratory of Biochemical Engineering, Institute of Process Engineering, Chinese Academy of Sciences, Beijing 100190, China

Full list of author information is available at the end of the article
}

bioproducts [6, 7], while most lignin cannot be utilized efficiently. Large amounts of lignin have been formed and estimated to be in the range $5-36 \times 10^{8}$ tons annually [8]. Among them, the biomass refinery and pulp/ paper industries contribute about $6.2 \times 10^{7}$ and $5 \times 10^{7}$ tons of lignin per year, respectively, including kraft lignin, lignosulfonate, and soda lignin [9]. In most cases, lignin is currently used for energy supply or discarded as waste. Lignin is a promising feedstock to produce biofuels and biochemicals owing to its high carbon-to-oxygen ratio and rich aromatic skeleton. To exploit lignin valorization, it is an urgent need to understand the degradation 
process and develop efficient metabolic pathway for conversion.

Lignin is an amorphous heteropolymer consisting of three phenylpropanoid units of guaiacyl alcohol, $p$-coumaryl alcohol, and syringyl alcohol, which are connected by the chemical bonds of aryl ether $(\beta-\mathrm{O}-4)$, phenylcoumaran $(\beta-5)$, resinol $(\beta-\beta)$, biphenyl ether (5-O-4), and dibenzodioxocin (5-5) [10] (Fig. 1). The complex structure and recalcitrance of lignin are the main challenges for its efficient depolymerization and utilization. Currently, thermochemical and biological approaches are the main methods for lignin depolymerization. Thermochemical processes including pyrolysis (thermolysis), gasification, hydrogenolysis, and chemical oxidation require stringent conditions, intensive energy input, and expensive facilities [11]. In contrast, the bioprocessing of lignin

\section{a Basic units}<smiles>OC/C=C/c1ccc(O)cc1</smiles>

p-coumaryl alcohol<smiles>COc1c(C)cc(C(=O)O[Na])cc1C</smiles>

p-hydroxyphenyl $\mathrm{H}$-unit<smiles>COc1cc(/C=C/CO)ccc1O</smiles>

coniferyl alcohol<smiles>COc1cc([N+](=O)[O-])cc(C)c1OC</smiles>

guaiacyl G-unit<smiles>COc1cc(/C=C/CO)cc(OC)c1O</smiles>

sinapyl alcohol<smiles>COc1cc([N+](=O)[O-])cc(OC)c1OC</smiles>

syrinayl

S-unit

\section{b Main linkages}<smiles>COc1cc(C(C)Oc2c(OC)cc(C(O)C(CO)Oc3c(C)cc(C(C)(C)C)cc3OC)cc2OC)cc(C)c1OC</smiles><smiles>COc1cc(C2Oc3c(OC)cc(C)cc3[C@@H]2CO)cc(C)c1OC</smiles>

phenylcoumaran $\beta-5$<smiles>COc1cc(OC)c(OC)c(-c2cc([N+](=O)[O-])cc(OC)c2OC)c1</smiles><smiles>COc1cc([18O])cc(C)c1Oc1cc(C(C)(C)C)cc(OC)c1OC</smiles>

biphenyl ehter 5-0-4

Fig. 1 Major backbone units and representative linkages in lignin molecule. a The building blocks of lignin consist of three primary types of monolignols, namely p-coumaryl alcohol, coniferyl alcohol, and sinapyl alcohol. The alcohols form the corresponding phenylpropanoid units like p-hydroxyphenyl $(H)$, guaiacyl $(G)$, and syringyl $(S)$ in lignin polymer, respectively. b Backbone units are conjugated via different chemical bonds (e.g., $\beta-0-4, \beta-\beta, 5-5$, and $\beta-5$ ) resulting in high resistance to lignin depolymerization 
has the advantage of high specificity, low-energy input, and cost-effectiveness [12]. The bioprocessing treatment with microorganism normally include two steps: native lignin is firstly degraded to heterogeneous aromatics, which then enter the central carbon metabolism [13]. So far, a large number of microorganisms including fungi and bacteria have been found to be able to degrade and metabolize lignin.

Lignin is mainly depolymerized by extracellular oxidases secreted by microorganisms such as lignin peroxidase ( $\mathrm{LiP})$, manganese peroxidase $(\mathrm{MnP})$, versatile peroxidase (VP), dye-decolorizing peroxidase (DyP), and laccase [14]. During the oxidation process, the unstable free radicals produced by the oxidase can attack lignin, and cleave the chemical bonds [15]. The resulted aromatic compounds were further metabolized by microbes via the enzymatic reactions [16] and $\beta$-ketoadipate pathway, and finally converted to valuable products. To now, lignin has been successfully manufactured into valueadded products of polyhydroxyalkanoates (bioplastic) [17], lipids (often used as biofuel) [18], animal feed additive [19], pesticides [20], compost (generally as biofertilizers) [21], vanillin [22], and muconic acid [23].

In the present review, we focused on the bioprocessing of lignin and bioconverting it to value-added bioproducts. The most recent development on lignin depolymerization by microorganisms, the microbial secreted oxidases, and the decomposition mechanism were summarized. Additionally, the metabolism of lignin-derived aromatics in different microorganisms was illustrated and the production of value-added products through microbial metabolic engineering was proposed.

\section{Lignin depolymerization by microorganisms and enzymes}

\section{Lignin depolymerization by fungi}

The depolymerization of lignin is critical for lignin utilization, and diverse lignin-degrading enzymes and metabolic system of microorganism have been evolved for lignin degradation and conversion [24]. Fungi are the most effective lignin-degrading microorganisms, which can secrete a variety of lignin-degrading enzymes. According to the degradation mechanism of lignin, the lignin-degrading fungi mainly include three types: whiterot, brown-rot, and soft-rot fungi [25]. Among the three lignin-degrading fungi, only white-rot fungi can completely degrade lignin to $\mathrm{CO}_{2}$ and $\mathrm{H}_{2} \mathrm{O}$ [26], and the typical fungi for lignin degradation are shown in Table 1.

White-rot fungi White-rot fungi are the main lignin degradation microorganism in nature, and its degradation ability is better than brown-rot and soft-rot fungi [25]. The lignin-degrading white-rot fungi include most strains of basidiomycetes and a few species of ascomycetes [27]. Among white-rot fungi, the species of Ceriporiopsis subvermispora, Phellinus pini, Ganoderma australe, and Phlebia tremellosa specifically degrade lignin and hemicellulose but not cellulose. However, other strains such as Phanerochaete chrysosporium, Trametes versicolor, Heterobasidion annosum, and Irpex lacteusare can simultaneously degrade cellulose, hemicellulose, and lignin [28, 29]. The main extracellular enzymes secreted by white-rot fungi for lignin-degrading were oxidases and peroxidases. The oxidative reactions catalyzed by oxidoreductase for lignin decomposition include the cleavage of carbon-carbon bonds and ether linkages, and the removal of side chain and aromatic rings [30].

$P$. chrysosporium is a model white rot fungus for lignin degradation, which has been applied for biological pretreatment of lignocellulosic biomass [31, 32]. The

Table 1 Fungi degradation of lignin in various biomass sources

\begin{tabular}{|c|c|c|c|c|}
\hline Microorganisms & Strains & Biomass materials & Lignin degradation & Ref \\
\hline \multirow[t]{7}{*}{ White-rot fungi } & Phanerochaete chrysosporium & Wheat straw and cornstalk & $30 \%$ and $34.3 \%$ & {$[31,32]$ (Singh et al., Zhao et al.) } \\
\hline & Pleurotus ostreatus & Rice straw & $41 \%$ & [154] (Taniguchi et al.) \\
\hline & Lentinula edode LE16 & Sugarcane bagasse & $87.6 \%$ & [34] (Dong et al.) \\
\hline & Phlebia sp. MG-60 & Oak wood & $40.7 \%$ & [35] (Kamei et al.) \\
\hline & Ceriporiopsis subvermispora & Pinus taeda wood chips & $22 \%$ & [36] (Guerra et al.) \\
\hline & Trametes versicolor & Radiata pine wood chips & $22 \%$ & [155](Shirkavand et al.) \\
\hline & Dichomytus squalens & Wheat straw & $34.1 \%$ & [44] (Knežević et al.) \\
\hline \multirow[t]{3}{*}{ Brown-rot fungi } & Gloeophyllum trabeum & Wafers of spruce wood & $16 \%$ & [42] (Yelle et al.) \\
\hline & Fomitopsis pinicola & Wheat straw & $32.4 \%$ & [44] (Knežević et al.) \\
\hline & Polyporus ostreiformis & Rice straw & $18.6 \%$ & [156] (Dey et al.) \\
\hline
\end{tabular}


enzymes of $\mathrm{MnP}$ and LiP produced by $P$. chrysosporium degrade lignin in a non-specific oxidative way [33]. The fungi of Lentinula edode LE16 and Pleurotus ostreatus PO45 were also found to degrade lignin of sugarcane bagasse by producing polyphenol oxidase (PPO) and $\mathrm{MnP}$ [34]. Some white rot fungal species can produce laccase and peroxidases for lignin oxidation and decomposition. Lignin of oak wood was directly converted to ethanol by fermentation with Phlebia sp. MG-60, and $\mathrm{MnP}$ and laccase were identified in the culture [35]. Subvermispora was applied for Pinus taeda wood chips bioprocessing in solid-state fermentation, the lignin of which was mainly degraded by the $\beta$-O-aryl ether cleavage by the $\mathrm{MnP}$ and laccase [36]. The laccase (Lcc1) isolated from Ganoderma tsugae can promote lignin decomposition, mycelium growth, pigment formation, and stipe elongation [37]. The lignin degradation property of white-rot fungi makes it useful in the biopulping process of paper industry. In addition, white-rot fungi have been applied to other industrial fields: bioremediation of soil and water and biorefinery of biomass [38, 39].

Brown-rot fungi and soft-rot fungi Brown-rot fungi grow primarily on softwoods and represent $7 \%$ of woodrotting basidiomycetes. The fungi can rapidly hydrolyze the component of cellulose and hemicellulose while just partially oxidize lignin. Brown-rot fungi were found to degrade lignin through hydroxyl radicals produced via Fenton oxidation chemistry [40]. The extracellular hydroquinones generated by brown-rot fungi can reduce $\mathrm{Fe}^{3+}$ of $\mathrm{Fe}$-oxalate complex to $\mathrm{Fe}^{2+}$, which then reacts with hydrogen peroxide $\left(\mathrm{H}_{2} \mathrm{O}_{2}\right)$ to generate hydroxyl radicals. The oxidized quinone can be converted to hydroquinone and achieve redox cycling [41].

Gloeophyllum trabeum can non-selectively break the intermonomer side-chain linkages of lignin, and its fermentation can cause $16 \%$ of lignin loss in spruce wood [42]. Yelle et al. [43] found that the content of the arylglycerol- $\beta$-aryl ether linkage of lignin decreased when aspen wood was treated with Postia placenta, which can produce an extracellular Fenton system and break lignin with hydroxyl radicals. It was identified that $32.4 \%$ of lignin was degraded by Fomitopsis pinicola after fermented for 2 weeks [44].

In addition to brown-rot fungi, soft-rot fungi can also degrade lignin by attacking the syringyl units [30]. Softrot fungi mainly include Ascomycetes and Deuteromycetes and preferentially degrade hardwood [45]. The soft-rot fungi Aspergillus niger and Penicillium chrysogenum were found to degrade pine and sycamore wood [46], and some soft-rot fungi can degrade vanillic acid and phenols rapidly [47]. While little is known about the enzymes of soft-rot fungi involved in degrading lignin, it was suggested that soft-rot fungi might modify rather than mineralize lignin.

\section{Lignin depolymerization by bacteria}

Apart from fungi, bacteria with lignin degradation ability have been identified from different habitats such as soil, rotten wood, wastewater treatment plant, and animal gut [48]. Although the lignin degradation performance of bacteria is inferior to fungi, bacteria have stronger environmental adaptability. Recent studies reported that Actinobacteria, Proteobacteria, and Firmicutes are major lignin-degrading bacteria [49]. Bacteria grow on lignin secrete oxidative enzymes to break lignin with the presence of oxygen. Moreover, lignin can be degraded by extreme anaerobic conditions, and the bacteria with capability of decomposing lignin are listed in Table2.

Aerobic bacteria Bacterial lignin depolymerization primarily occurs under aerobic conditions [50].

Table 2 Bacteria degradation of lignin in various biomass sources

\begin{tabular}{|c|c|c|c|c|}
\hline Microorganisms & Strains & Biomass materials & Lignin degradation & Ref \\
\hline \multirow[t]{8}{*}{ Aerobic bacteria } & Streptomyces viridosporus T7A & $\begin{array}{l}\text { Softwood spruce, hardwood } \\
\text { maple and grass }\end{array}$ & $30.9 \%, 32 \%$, and $44.2 \%$ & [52] (Antai, Crawford) \\
\hline & Rhodoccocus Jostii RHA1 & Soluble and lignin-rich stream & $18.9 \%$ & [55] (Salvachúa et al.) \\
\hline & R. pyridinivorans CCZU-B16 & Alkali lignin & $30.2 \%$ & [128] (Chong et al.) \\
\hline & Pseudomonas putida KT2440 & Alkaline pretreated liquor & $\sim 30 \%$ & [58] (Salvachúa et al.) \\
\hline & P. putida NX-1 & Kraft lignin & $28.5 \%$ & [59] (Xu et al.) \\
\hline & Comamonas sp. B-9 & Kraft lignin & $45 \%$ & [61] (Chai et al.) \\
\hline & Bacillus ligniniphilus L1 & Alkaline lignin & $38.9 \%$ & [62] (Zhu et al.) \\
\hline & B. amyloliquefaciens SL-7 & Tobacco straw lignin & $28.55 \%$ & [63] (Mei et al.) \\
\hline \multirow[t]{2}{*}{ Facultative anaerobe bacteria } & Enterobacter lignolyticus SCF1 & Alkali lignin & $56 \%$ & [68] (DeAngelis et al.) \\
\hline & Acetoanaerobium sp & Kraft lignin & $24.9 \%$ & [71] (Duan et al.) \\
\hline \multirow[t]{2}{*}{ Extremophile bacteria } & Caldicellulosiruptor kronotskyensis & Natural rice straw & $52.5 \%$ & [74] (Peng et al.) \\
\hline & Arthrobacter sp. C2 & Sodium lignin sulfonate & $40.1 \%$ & [75] (Jiang et al.) \\
\hline
\end{tabular}


Streptomyces and Rhodoccocus of Actinobacteria are typical bacteria for lignin degradation. Streptomyces viridosporus T7A decompose lignin by extracellular enzymes secreted by filamentous form [13]. S. viridosporus T7A can degrade lignin of native wheat straw, and the guaiacyl units reduced [51]. Approximately 30 45\% of the lignin from softwood, hardwood, and grass was removed after fermentation with S. viridosporus T7A and S. setonii $75 \mathrm{Vi2}$ for 12 weeks [52]. Rhodoccocus is considered as a robust microorganism for lignin breakdown, as it has excellent tolerance and hydrolytic activity for toxic metabolites. The polychlorinated biphenyl-degrading soil bacterium $R$. jostii RHA1 can convert kraft lignin and wheat straw to aromatic dicarboxylic acids and vanillin, and around 19\% of lignin can be utilized [53-55]. The dyp-type peroxidase DypB from $R$. jostii RHA1 was identified to break $\beta$-aryl ether linkage in lignin model compound [56]. R. erythropolis isolated from wood and soil also showed high degrading activity on nitratedlignin of wheat straw [57]. The Proteobacteria containing Pseudomonas, Pandoraea, and Comamonas genus, etc. were applied for lignin depolymerization. It was found that $30 \%$ lignin of alkaline pretreated liquor (APL) were depolymerize and catabolize by $P$. putida KT2440 and $P$. putida $\mathrm{mt}-2$ [58]. P. putida NX-1 could utilize kraft lignin as the sole carbon source for cell growth and secrete extracellular ligninolytic enzymes [59]. P. putida is an excellent chassis bacterium for converting lignin-derived aromatics to bio-based products through metabolic engineering. Pandoraea sp. B-6 was also found to efficiently degrade kraft lignin and produce low-molecular-weight aromatic and acid-type compounds [60]. The decolorization and depolymerization of kraft lignin by Comamonas sp. B- 9 were $54 \%$ and $45 \%$, respectively, after 7 days of treatment [61]. Bacillus genus of Firmicutes with lignindegrading ability was identified through high-throughput sequencing. Fifteen kinds of phenol ring aromatic compounds were generated from alkaline lignin processed with Bacillus ligniniphilus L1 [62]. Three kinds of lignin degradation pathways of gentisate, benzoic acid, and $\beta$-ketoadipate were identified in Bacillus through genomic and proteomic analysis. Bacillus amyloliquefaciens SL-7 can grow on tobacco straw lignin and secreted ligninolytic enzymes [63].

Anaerobic bacteria In addition to aerobic bacteria, anaerobic bacteria have been identified to convert lignin and its derived aromatics to methane and carbon dioxide. The degradation performance of modified lignin under anaerobic conditions is better than that of natural lignin, which has a high degree of methoxylation [64]. The methoxy group is the main attacking point for many bacteria during anaerobic degradation of methoxylated aromatics. The anaerobic process of lignin degradation mainly includes demethoxylation, aromatic ring cleavage, and methanogenesis [65]. Lignin-derived aromatics was converted to methane by anaerobically digestion by methanogenic microbial communities [66]. Many bacteria have been identified to be capable of degrading lignin in anaerobic environments. A facultative anaerobe Enterobacter lignolyticus SCF1 was isolated from tropical forest soil with alkali-treated lignin as the sole carbon source [67]. The genes of catalase/peroxidase and glutathione S-transferases for lignin degradation via 4-hydroxyphenylacetate pathway were up-regulated by transcriptomic and proteomic analyses [68]. Tolumonas lignolytica BRL6-1 and Klebsiella sp. strain BRL6-2 were isolated and characterized as anaerobic lignin-degrading bacteria, and several putative enzymes for lignin degrading were identified [69, 70]. Acetoanaerobium sp. WJDL-Y2 was identified from the sludge of a pulp and paper mill, which can oxidize kraft lignin to low-molecular-weight aromatic and acid compounds such as syringic acid, ferulic acid, and hexanoic acid [71].

Extremophile bacteria With the special enzymes and metabolic pathways, the extremophile bacteria were more competitive for lignin degradation and utilization. The thermophilic bacteria showed promising potential for the degradation and transformation of lignin. The Dyp-type peroxidase from Thermobifida fusca can degrade kraft lignin and oxidize a $\beta$-aryl ether lignin model compound [72]. When the hardwood of Populus trichocarpa was processed with the anaerobic thermophile Clostridium thermocellum, the $\beta-\mathrm{O}-4$ linkage content was reduced and syringyl/guaiacyl $(S / G)$ ratio in lignin was increased [73]. The extremely thermophilic bacterium Caldicellulosiruptor kronotskyensis can degrade natural rice straw without pretreatment, and produce solubilized carbohydrates, organic acids, and lignin-derived aromatics [74]. Besides, lignin degradation was also detected by a psychrotrophic bacteria Arthrobacter sp. C2 at low temperature, and the intermediates of acids, phenols, aldehydes, and alcohols were identified after the treatment [75].

\section{Lignin depolymerization by enzymes}

The microbial degradation of lignin was conducted by a serious of oxidative enzymes. An increasing number of lignin-degrading enzymes have been discovered and applied in the processes of lignin depolymerization and mineralization from fungi and bacteria As the major enzymes for lignin degradation, phenol oxidase (laccase) and heme-containing peroxidases (lignin peroxidase, manganese peroxidase, and versatile peroxidase) have attracted considerable attention [76]. The in vitro enzymatic synthesis has been applied for lignin conversion, which avoids the cell culture, obstacle of substrate transport, and $\mathrm{NAD}(\mathrm{P}) \mathrm{H}$ and ATP imbalance [77]. The 
properties of typical ligninolytic enzymes are listed in Table 3 , and the reactions and catalytic mechanisms were discussed.

\section{Laccase}

Laccase is a multi-copper oxidase present in fungi, plants, and bacteria, and the fungal laccase usually has higher reduction potential than that of plants and bacteria. The structure of laccase from Trametes versicolor has been characterized (Fig. 2a) [78]. It contains approximately 500 amino acid residues and three copper sites: type 1 (one $\mathrm{Cu}$ atom), type 2 (one $\mathrm{Cu}$ atom), and type 3 (two $\mathrm{Cu}$ atoms) per molecule of laccase. In the reaction catalyzed by type 1 laccase, four electrons are transferred to the tri-nuclear center via a His-Cys-His tripeptide pathway. Both phenolic and non-phenolic compounds can be degraded by laccase with oxygen as a final electron acceptor (Fig. 3a) [79]. The oxidation of phenolic substrates by laccase forms phenoxyl free radical as an unstable intermediate, which then promotes $\mathrm{C} \alpha$ oxidation, alkyl-aryl cleavage, and $\mathrm{C} \alpha-\mathrm{C} \beta$ cleavage [80]. Laccase needs to cooperate with the mediators like 1-hydroxybenzotriazole (HBT), 3-hydroxyanthranilic acid (HAA), and 2, 2'-azinobis-(3-ethylbenzothiazoline-6-sulfonate) (ABTS) in degrading non-phenolic substrates. The oxidized non-phenolic compounds coupled with mediators can promote the aromatic ring cleavage, $C \alpha-C \beta$ cleavage, $C \alpha$ oxidation, and $\beta$ ether cleavage [81]. It is generally agreed that mediators enhance the oxidation capabilities of laccase and help overcome the steric hindrance existing between laccase and substrate. With the help of these mediators, laccase also can be applied in delignification process. The laccase of Trametes villosa could remove about $48 \%$ and $32 \%$ of lignin, respectively, from Eucalyptus globulus and Pennisetum purpureum feedstocks with 2.5\% HBT as a mediator [82]. Different methods have been carried out to improve laccase yield of microbes including novel fermentation methods, genetic modifications, and addition of cofactors or inducer. Previous studies also found that the microbes can still degrade lignin in the absence of laccase, which suggested that laccase is the essential enzyme for lignin depolymerization $[83,84]$.

\section{Lignin peroxidase (LiP)}

$\mathrm{LiP}$ is a glycoprotein with molecular mass of 38-43 kilodalton $(\mathrm{kDa})$ and isoelectric point $(\mathrm{pI})$ of 3.3-4.7 [76]. The crystal structure of LiP in P. chrysosporium was mainly constituted of $\alpha$-helices (Fig. 2b) [85], and there are two calcium ions and four disulfide bonds to stabilize the three-dimensional structure. The active site of LiP is composed of a heme-containing iron atom. The trp171 residue conserved in LiP sequences is essential for the catalytic activity of LiP. LiP oxidizes both non-phenolic and phenolic compounds with $\mathrm{H}_{2} \mathrm{O}_{2}$ and veratryl alcohol (VA) as electron donor and cofactor (Fig. 3b). Generally, the enzymatic reaction of LiPmediated lignin degradation consists of one oxidation and two reduction steps. The oxoferryl iron porphyrin radical cation $\left[\mathrm{Fe}(\mathrm{IV})=\mathrm{O}^{+}\right]$is formed by the oxidation of ferric [Fe(III)] LiP along with the reduction of $\mathrm{H}_{2} \mathrm{O}_{2}$ to water. Then, $\left[\mathrm{Fe}(\mathrm{IV})=\mathrm{O}^{+}\right]$was converted to two $[\mathrm{Fe}(\mathrm{IV})=\mathrm{O}]$ through two consecutive one-electron reduction steps and complete catalytic cycle $[86,87]$. LiP can degrade a variety of phenolic and nonphenolic

Table 3 Characteristics and reaction of major ligninolytic enzymes $[157,158]$

\begin{tabular}{|c|c|c|c|}
\hline Enzyme & Source & Substrate & General reaction \\
\hline $\begin{array}{l}\text { Laccase } \\
\text { EC 1.10.3.2 }\end{array}$ & $\begin{array}{l}\text { Widely distributed in fungi and bacteria } \\
\text { (e.g., Ascomycetes, Basidiomycetes and } \\
\text { Streptomyces) }\end{array}$ & $\begin{array}{l}\text { Phenolic compounds, aromatic amines } \\
\text { and } \\
\text { dye molecules }\end{array}$ & $\begin{array}{l}4 \text { benzenediol }+\mathrm{O}_{2} \rightleftharpoons 4 \text { benzosemiqui- } \\
\text { none }+2 \mathrm{H}_{2} \mathrm{O}\end{array}$ \\
\hline $\begin{array}{l}\text { Lignin peroxidase } \\
\text { EC 1.11.1.14 }\end{array}$ & $\begin{array}{l}\text { White rot fungal genera (e.g., Bjerkan- } \\
\text { dera, Phanerochaete, Phlebia and } \\
\text { Trametes) }\end{array}$ & $\begin{array}{l}\text { Phenols, aromatic amines, aromatic } \\
\text { ethers and polycyclic aromatics }\end{array}$ & $\begin{array}{l}\text { 1,2-bis(3,4-dimethoxyphenyl)propane- } \\
\text { 1,3-diol }+\mathrm{H}_{2} \mathrm{O}_{2} \rightleftharpoons 3,4 \text {-dimethoxyben- } \\
\text { zaldehyde }+1 \text { - }(3,4 \text {-dimethoxyphenyl) } \\
\text { ethane-1,2-diol }+\mathrm{H}_{2} \mathrm{O}\end{array}$ \\
\hline $\begin{array}{l}\text { Manganese peroxidase } \\
\text { EC 1.11.1.13 }\end{array}$ & $\begin{array}{l}\text { Wood and litter-decomposing white rot } \\
\text { fungi (e.g., Dichomitus squalens, Agari- } \\
\text { cus bisporus and Agrocybe praecox) }\end{array}$ & Phenolic compounds & $2 \mathrm{Mn}(\mathrm{II})+2 \mathrm{H}^{+}+\mathrm{H}_{2} \mathrm{O}_{2} \rightleftharpoons 2 \mathrm{Mn}(\mathrm{III})+2 \mathrm{H}_{2} \mathrm{O}$ \\
\hline $\begin{array}{l}\text { Versatile peroxidase } \\
\text { EC 1.11.1.16 }\end{array}$ & $\begin{array}{l}\text { White rot species (e.g., Pleurotus ostrea- } \\
\text { tus, Bjerkandera adusta) }\end{array}$ & $\begin{array}{l}\text { High-redox-potential } \\
\text { aromatic compounds and recalcitrant } \\
\text { dyes }\end{array}$ & $\begin{array}{l}\text { (1) Reactive Black } 5+\mathrm{H}_{2} \mathrm{O}_{2} \rightleftharpoons \text { oxidized } \\
\text { Reactive Black } 5+2 \mathrm{H}_{2} \mathrm{O} \\
\text { (2) Donor }+\mathrm{H}_{2} \mathrm{O}_{2}=\text { oxidized donor }+2 \\
\mathrm{H}_{2} \mathrm{O}\end{array}$ \\
\hline $\begin{array}{l}\text { Dye-decolorizing } \\
\text { peroxidase } \\
\text { EC 1.11.1.19 }\end{array}$ & $\begin{array}{l}\text { Fungi and bacteria (e.g., Ascomycetes, } \\
\text { Basidiomycetes and Bacillus) }\end{array}$ & $\begin{array}{l}\text { Dye } \\
\text { compounds, carotenoids and phenolics }\end{array}$ & $\begin{array}{l}\text { Reactive Blue } 5+2 \mathrm{H}_{2} \mathrm{O}_{2} \rightleftharpoons \text { phtha- } \\
\text { late }+2,2^{\prime} \text {-disulfonyl azoben- } \\
\text { zene }+3 \text {-[(4-amino-6-chloro-1,3,5- } \\
\text { triazin-2-yl)amino] } \\
\text { benzenesulfonate }+2 \mathrm{H}_{2} \mathrm{O}\end{array}$ \\
\hline
\end{tabular}



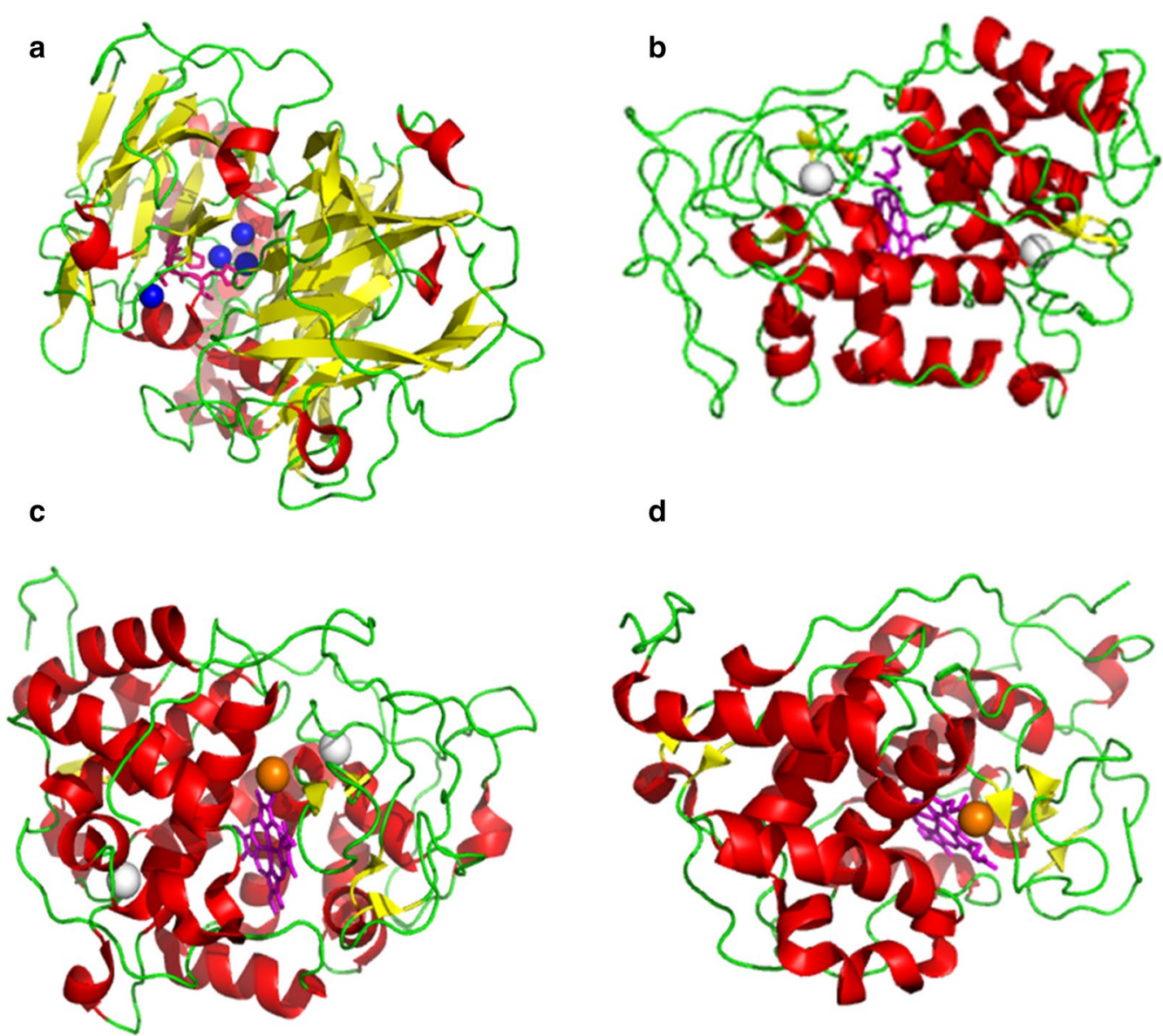

Fig. 2 Structures of ligninolytic enzymes. The red, yellow, and green colored regions represent a-helix, $\beta$-sheet, and random coil, respectively. a Laccase (PDB ID: 1GYC) from Trametes versicolor [78] has a well-conserved active site with four copper, and T1 copper is connected to the trinuclear cluster by a His-Cys-His tripeptide. b Lip (PDB ID: 1LGA) of Phanerochaete chrysosporium [85] contains two calcium ions, four disulfide bonds, and a heme-containing one iron atom as its active site. c MnP (PDB ID: 1YYD) from P. chrysosporium [89] shows the active sites of Glu35, Glu39, and Asp179 residues as well as the $\mathrm{Mn}^{2+}$ ion. $\mathbf{d}$ VP (PDB ID: 2BOQ) of Pleurotus eryngii [94] exhibits an $\mathrm{Mn}^{2+}$-binding site and an external Trp residue. The electron transfer pathway towards heme is obtained directly from $\mathrm{Mn}^{2+}$ or relatively long range from Trp

\section{(See figure on next page.)}

Fig. 3 Catalytic mechanism of ligninolytic enzymes mediated lignin degradation. a Laccases not only directly oxidize phenolic compounds, but also degrade non-phenolic substrates of lignin in the presence of chemical mediators [79]. Molecular oxygen is reduced into water. $\mathbf{b}$ LiP indirectly degrades lignin via oxidizing veratryl alcohol to the corresponding diffusible cation radical as a direct oxidant on lignin. Two electrons of the native ferric enzyme are oxidized by $\mathrm{H}_{2} \mathrm{O}_{2}$ to form compound one, which receives one electron to form compound two. Finally, compound two is returned to the resting native ferric state by gaining one more electron from the reducing substrate $[86,87]$. c MnP oxidizes the one-electron donor $\mathrm{Mn}^{2+}$ to $\mathrm{Mn}^{3+}$, which in turn oxidizes a large number of phenolic substrates. The native ferric enzyme initially reacts with $\mathrm{H}_{2} \mathrm{O}_{2}$ to form compound one, and an $\mathrm{Mn}^{2+}$ ion donates one electron to the porphyrin intermediate to form compound two. The native enzyme is similarly produced from compound two by obtaining one electron from $\mathrm{Mn}^{2+}[90,91]$. $\mathbf{d}$ The basic catalytic cycle of VP is similar to the MnP and LiP with the two intermediary compounds one and two

compounds, and hence, it is a candidate for lignin depolymerization. Compared to other peroxidases, LiP is the major enzyme responsible for lignin degradation due to its high reduction potential. It was found that
LiP produced in liquid-state fermentation of Aspegillus oryzae CGMCC 5992 showed high activity on lignin of corn stover pretreated with $\mathrm{H}_{2} \mathrm{O}_{2}$ [88], and the addition of mineral nutrients and gene modification were conducted to enhance LiP yield. 
a Laccase<smiles>On1nnc2ccccc21</smiles><smiles>CCn1c(=N)sc2cc(O)ccc21</smiles>
OH ABTS<smiles></smiles>
HO<smiles>Nc1c(O)cccc1C(=O)O</smiles>
HAA

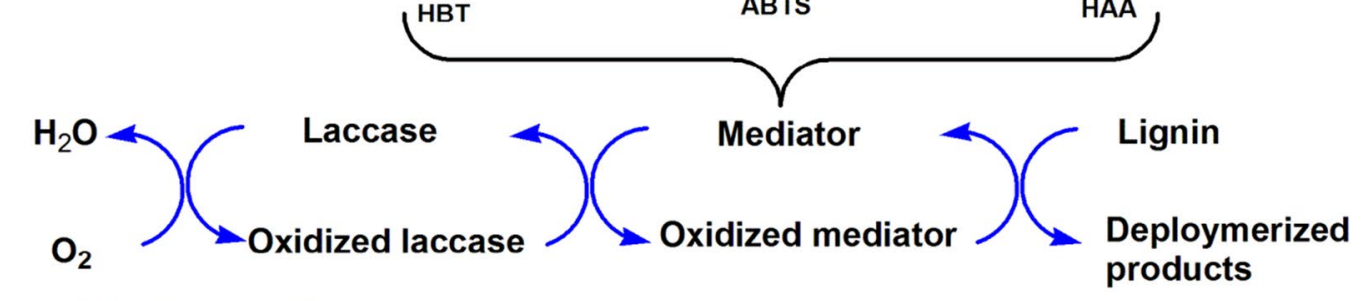

b Lignin peroxidase
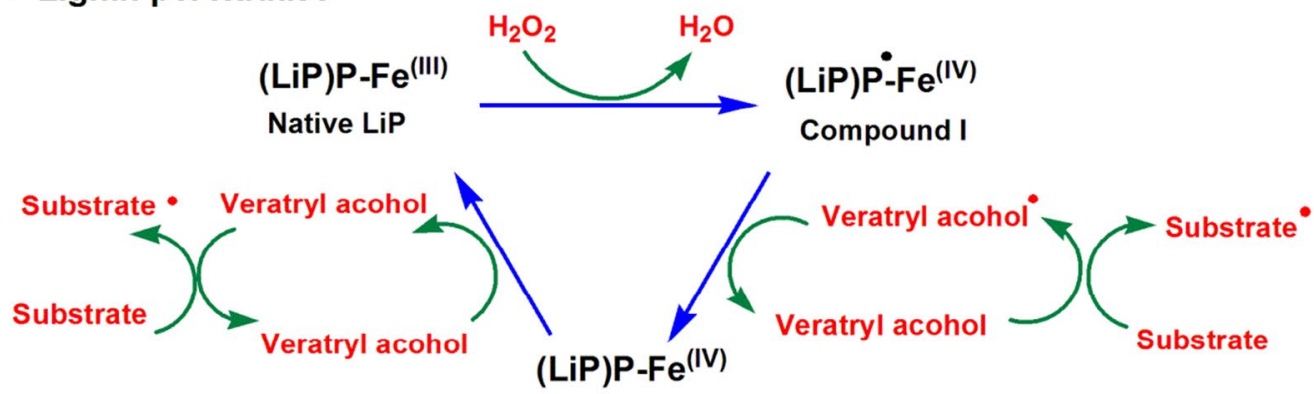

Compound II

c Manganese peroxidase
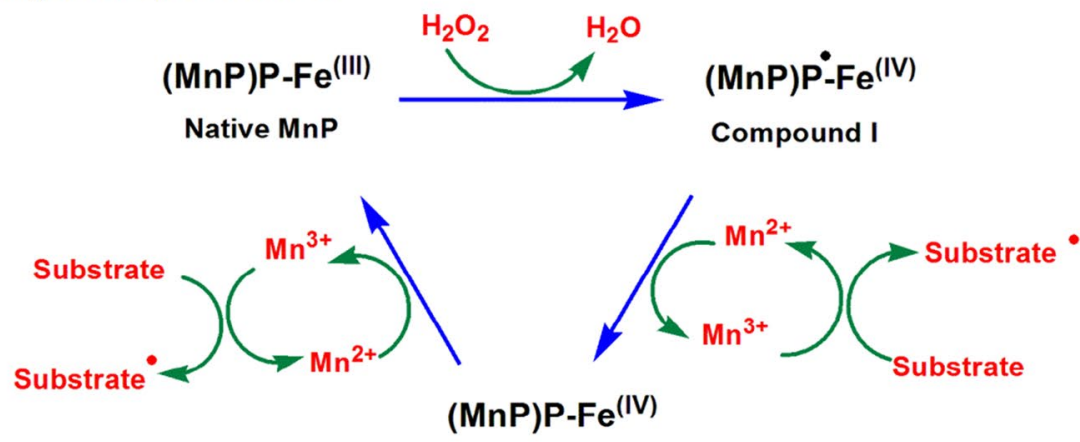

Compound II

\section{d Versatile peroxidase}

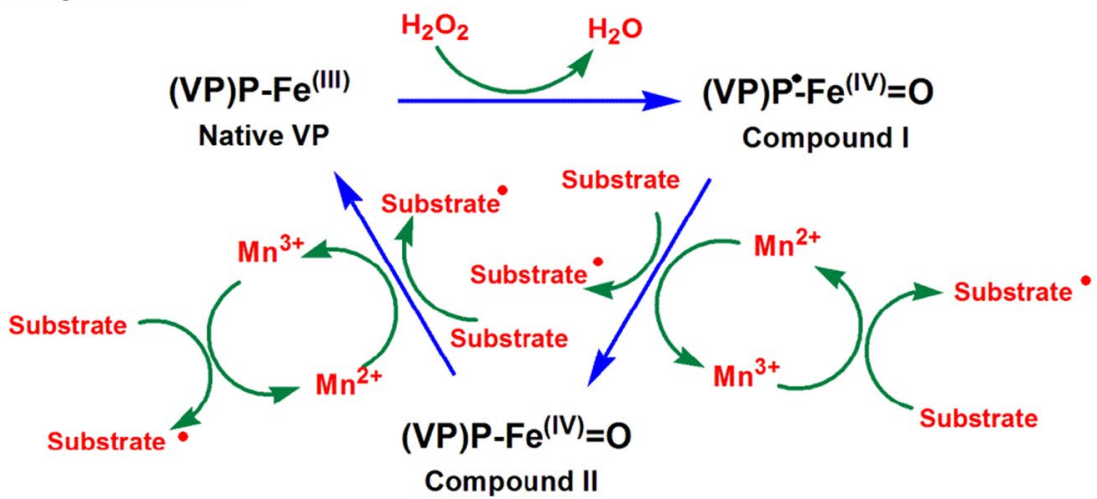




\section{Manganese peroxidase ( $\mathrm{MnP}$ )}

$\mathrm{MnP}$ is a glycosylated heme-protein with a molecular weight of $45 \sim 60 \mathrm{kDa}$ [76], and it is the main ligninolytic peroxidase of basidiomycetes. The crystal structure of MnP from $P$. chrysosporium was published and presents similarities to Lip (Fig. 2c) [89], and it includes an $\mathrm{Mn}^{2+}$ ion, one heme propionate, and the side chains of Glu35, Glu39, and Asp179. The lignin degradation catalyzed by $\mathrm{MnP}$ includes both oxidation and reduction steps (Fig. 3c). MnP initiates the catalytic cycle by binding $\mathrm{H}_{2} \mathrm{O}_{2}$ to the native ferric enzyme. Afterward, MnP oxidizes $\mathrm{Mn}^{2+}$ to $\mathrm{Mn}^{3+}$ in the presence of chelators, and the generated $\mathrm{Mn}^{3+}$ then convert lignin phenolic compounds to phenoxy-radicals. The organic acid chelators like oxalate and malonate can stabilize $\mathrm{Mn}^{3+}$ and stimulate the enzyme activity $[90,91]$. Similar to LiP, MnP plays an important role in the initial depolymerization of lignin. Moreover, it was found that adding MnP to the culture medium can accelerate lignin depolymerization. It was found that $\mathrm{MnP}$ can promote lignin degradation and methane yield, and $68.4 \%$ of lignin from municipal solid waste was removed by $\mathrm{MnP}$ [92].

\section{Versatile peroxidase (VP)}

$\mathrm{VP}$ is a unique lignin-degrading enzyme and is found in white-rot fungal genera Pleurotus and Bjerkandera [93]. The crystal structure of VP from Pleurotus eryngii is similar to LiP and MnP of P. chrysosporium (Fig. 2d) [94]. An $\mathrm{Mn}^{2+}$-binding site was found in the protein structure allowing a direct transfer of electrons to the heme. And a tryptophan residue revealed the possibility of long-range electron transfer to oxidate aromatic compounds at the protein surface. VP has a broad substrate preference as containing a heme access channel, a catalytic tryptophan, and an Mn oxidation site. VP is termed as hybrid peroxidase, which exhibits similar catalytic mechanisms with both LiP and MnP (Fig. 3d). However, VP can degrade directly high reduction potential substrates without the presence of VA and oxidizing $\mathrm{Mn}^{2+}$ independently, which is different from MnP and LiP [95]. VP has obtained research interests in biotechnological applications and genetic manipulations due to its special bifunctionality. The VP of Physisporinus vitreus was used to reduce the saccharification recalcitrance and improve the enzymatic hydrolysis of corn stover [96]. The VP of Bjerkandera adusta was cloned and over-expressed in Escherichia coli for the large-scale production [97].

\section{$\beta$-Etherase}

Besides peroxidase, $\beta$-etherases have been discovered to degrade lignin fragments in vivo, which could break $\beta$-aryl ether and biphenyl linkages within lignin molecules. The $\beta$-etherases involved in $\beta-\mathrm{O}-4$ ether and biphenyl catabolic pathways provide a reliable method to depolymerize and convert lignin.

The $\beta-\mathrm{O}-4$ ether bond is the most prevalent linkage and accounts for more than $50 \%$ of all ether linkages in lignin [98], so its breakdown is critical for lignin depolymerization. Recently, the enzymatic cleavage of $\beta-\mathrm{O}-4$ ether bond (Fig. 4) was studied in bacteria of Sphingobium sp. SYK-6, Novosphingobium sp. PP1Y, and Dichomitus squalens [99-101]. The degradation of $\beta-\mathrm{O}-4$ ether bond starts with $\mathrm{C} \alpha$-dehydrogenase $\operatorname{LigD}$ that oxidizes the hydroxyl group at $\mathrm{C} \alpha$ position with the consumption of $\mathrm{NAD}^{+}$. Subsequently, $\beta$-etherase LigE or LigF cleaves the intermediate to $\alpha$-glutathionyl- $\beta$-hydroxypropiovanillone (GS-HPV) with glutathione at its $C \beta$ position. While the glutathione is oxidized to glutathione (GSSG) by glutathione lyase LigG and releases the final product of $\beta$-hydroxyproppiovanillone (HPV) [102]. The enzymes of LigD, E, F, and G were crucial for lignin degradation, and the complete set of genes LigD, LigF, and LigG were expressed heterologously in Arabidopsis thaliana to cleave $\beta-\mathrm{O}-4$ aryl ether bond, which enhanced lignin digestibility [103].

\section{Biphenyl bond cleavage enzyme}

Biphenyl linkage is another major bond and makes up approximately $10 \%$ in softwood lignin [104]. Biphenyl linkages are also exist polychlorinated biphenyls (PCB), which are important environmental pollutants and carcinogens [105], and the degradation process of PCB has been extensively studied (Fig. 4). In the catalytic process of 5, 5'-dehydrodivanillate (DDVA) by non-heme iron-dependent demethylase enzyme LigX, one methoxy group is initially removed to form a hydroxyl group [106]. The product of LigX is the substrate for oxidative metacleavage via the extradiol dioxygenase LigZ [107]. Then, the $\mathrm{C}-\mathrm{C}$ hydrolase LigY convert the ring fission product to 4-carboxy-2-hydroxypentadienoic acid and 5-carboxyvanillic acid (5CVA). Finally, the decarboxylases LigW and LigW2 transform 5CVA to the metabolic central intermediate vanillic acid or vanillate for the synthesis of bioproducts [108]. The cleavage of bi-phenyl linkage has been proved that it can promote lignin degradation.

\section{Biodegradation of lignin-derived aromatic compounds}

Lignin depolymerization by microorganisms yields a heterogeneous mixture of low-molecular-weight aromatic compounds, which have certain toxicity and inhibit the growth of microorganisms. In nature, several bacteria have been reported to use the lignin-derived aromatics as carbon and energy sources for cell growth and value-added products accumulation [109]. Biological lignin degradation usually include three stages: lignin 


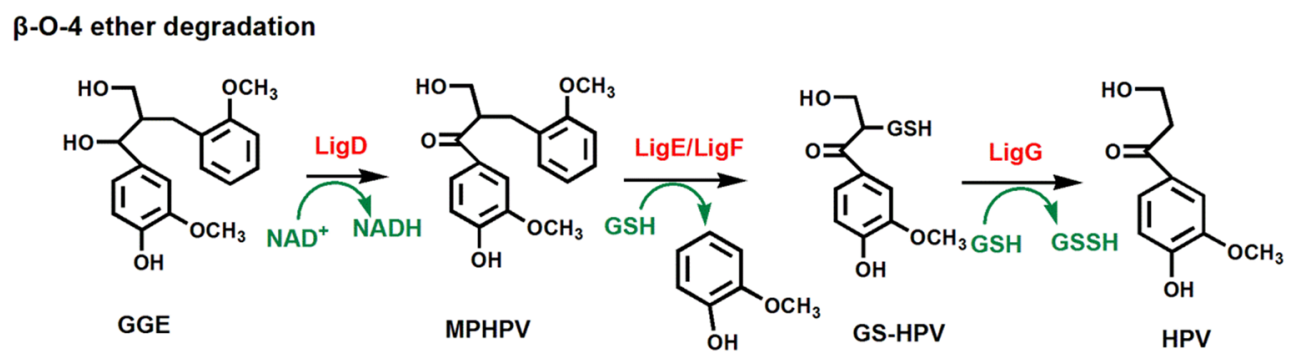

Bi-phenyl degradation

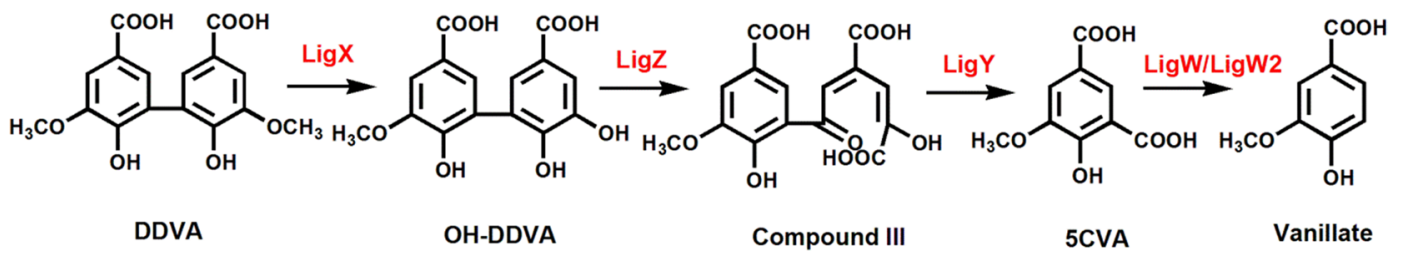

Fig. 4 Mechanisms of $\beta-O-4$ ether and biphenyl linkage degradation. The enzymes involved in the breakdown of $\beta-O-4$ aryl ether and biphenyl bonds in bacteria are identified and characterized. In $\beta-0-4$ ether degradation, guaiacylglycerol- $\beta$-guaiacylethe (GGE) is first degraded to a-(2-met hoxyphenoxy)- $\beta$-hydroxypropiovanillone (MPHPV), which is then converted to a-glutathionyl-HPV (GS-HPV) and $\beta$-hydroxyproppiovanillone (HPV) by LigD (Ca-dehydrogenase), LigE/LigF ( $\beta$-etherase), and LigG (glutathione lyase) [102]. In biphenyl degradation, 5, 5'-dehydrodivanillate (DDVA) is initially O-demethylated to form 2,2'-3-trihydroxy-3'-methoxy-5,5'-dicarboxybiphenyl (OH-DDVA) by LigX (non-heme iron-dependent demethylase enzyme). The generated substrate is oxidated and cleaved by LigZ (extradiol dioxygenase) and LigY (C-C hydrolase) to produce 5-carboxyvanillic acid (5CVA). Eventually, 5CVA is transformed into the central intermediate vanillic acid by LigW and LigW2 (two decarboxylase enzymes) [106, 108]

depolymerization, aromatics catabolism, and ring cleavage, the carbon of aromatic compounds ultimately integrates into TCA cycle (Fig. 5). The degradation of lignin produces three categories of monolignols (G-lignin, $\mathrm{H}$-lignin, and S-lignin), which can be assimilated by various bacteria through different metabolic pathways.

\section{Degradation of $\mathrm{H}$-lignin-based derivatives}

The H-lignin-based derivatives ( $p$-coumaric acid) possess simple structure and low lignin content, which accounts for $0.3 \%, 1.7 \%, 2.8 \%$, and $2.8 \%$ of the lignin in poplar (hardwood), pine (softwood), corn (monocotyledon), and Arabidopsis (dicotyledon), respectively [110]. Generally, the degradation pathways of $p$-coumaric acid in bacteria can be categorized as $\mathrm{CoA}$-dependent $\beta$-oxidation pathway, CoA-dependent non- $\beta$-oxidation pathway, and CoA-independent pathway [111]. The generated intermediate of 4-hydroxybenzoate was hydroxylated to protocatechuic acid by 4-hydroxybenzoic acid-3-hydroxylase (Fig. 6). Among the three pathways, the CoA-dependent non- $\beta$-oxidation pathway of $p$-coumaric acid mainly occurs in Rhodococcus sp., Sphingomonas sp., and Sphingobium sp. [112-114]. Burkholderia glumae BGR1 was identified to catabolize $p$-coumaric acid via CoA-dependent non- $\beta$-oxidation pathway, the $p$-coumaric acid was converted to $p$-hydroxybenzaldehyde by $p$-hydroxycinnamoyl CoA synthetase (pHCS) and $p$-hydroxycinnamoyl
CoA hydratase/lyase (pHCHL), and then oxidized to $p$-hydroxybenzoic acid by benzaldehyde dehydrogenase (BADH). The generated $p$-hydroxybenzoic acid undergoes a hydroxylation reaction to form protocatechuic acid [115]. Besides the protocatechuate pathway, new gentisate pathway for 4-hydroxybenzoate metabolism has been found in Haloarcula sp. strain D1, Bacillus ligniniphilus L1, and Candida parapsilosis $[62,116,117]$.

\section{Degradation of G-lignin-based derivatives}

The G-lignin-based derivatives (ferulic acid) have a methoxy group on the aromatic ring, which constitutes $37.8 \%, 98.3 \%, 38.3 \%$, and $77.1 \%$ of the lignin in poplar, pine, corn, and Arabidopsis respectively [110]. Ferulic acid can be converted to the intermediate vanillic acid rather than 4-hydroxybenzoate, through four different metabolic pathways of non-oxidative decarboxylation pathway, CoA-dependent $\beta$-oxidation pathway, CoAdependent non- $\beta$-oxidation pathway, and side chain reduction pathway [118]. Under the catalysis of vanillate demethylase, vanillic acid is demethylated and transformed to protocatechuic acid (Fig. 6). Pseudomonas fluorescens BF13 and Pseudomonas putida KT2440 can degrade ferulic acid via CoA-dependent non- $\beta$-oxidation pathway. Ferulic acid is catalyzed to feruloyl-CoA by feruloyl-CoA synthetase $(f c s)$, and then converted to vanillin and acetyl-CoA by enoyl-CoA hydratase/aldolase (ech). 


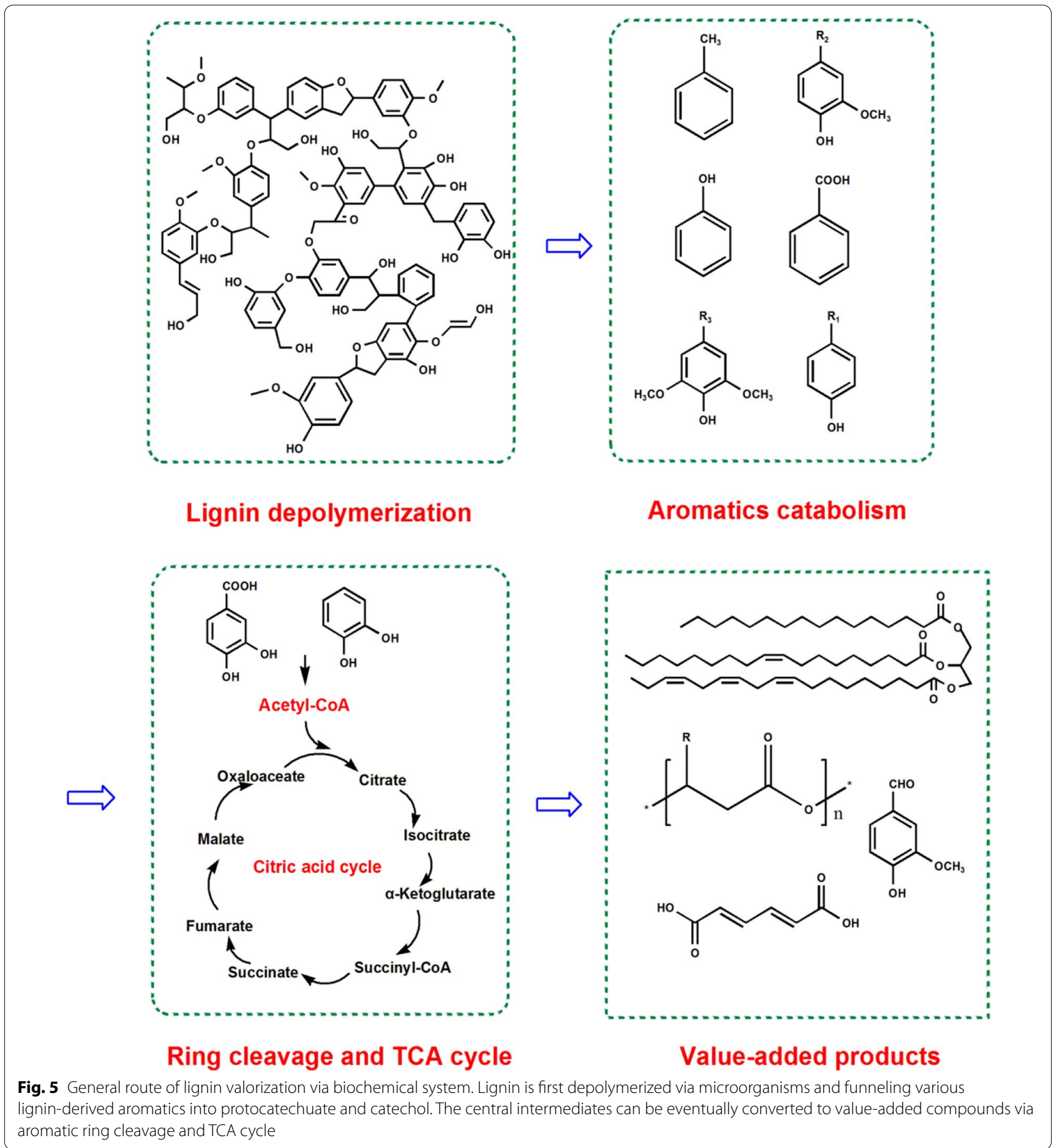

\section{(See figure on next page.)}

Fig. 6 Degradation pathways for lignin-based aromatic compounds. H-lignin (p-coumaric acid) can be degraded to protocatechuic acid through three different pathways: CoA-independent pathway, CoA-dependent non- $\beta$-oxidation pathway, and CoA dependent $\beta$-oxidation pathway [1 11 ]. The degradation pathway of G-lignin (ferulic acid) can be divided into non-oxidative decarboxylation pathway, CoA-dependent non- $\beta$-oxidation pathway, CoA-dependent $\beta$-oxidation pathway, and side chain reduction pathway [1 18]. These four pathways are all transformed into vanillic acid involved with different intermediates and enzymes. S-lignin (syringic acid) is assimilated into 4-oxalomesaconate derived from the protocatechuic acid 4, 5-cleavage pathway via a series of enzyme reactions [120] 


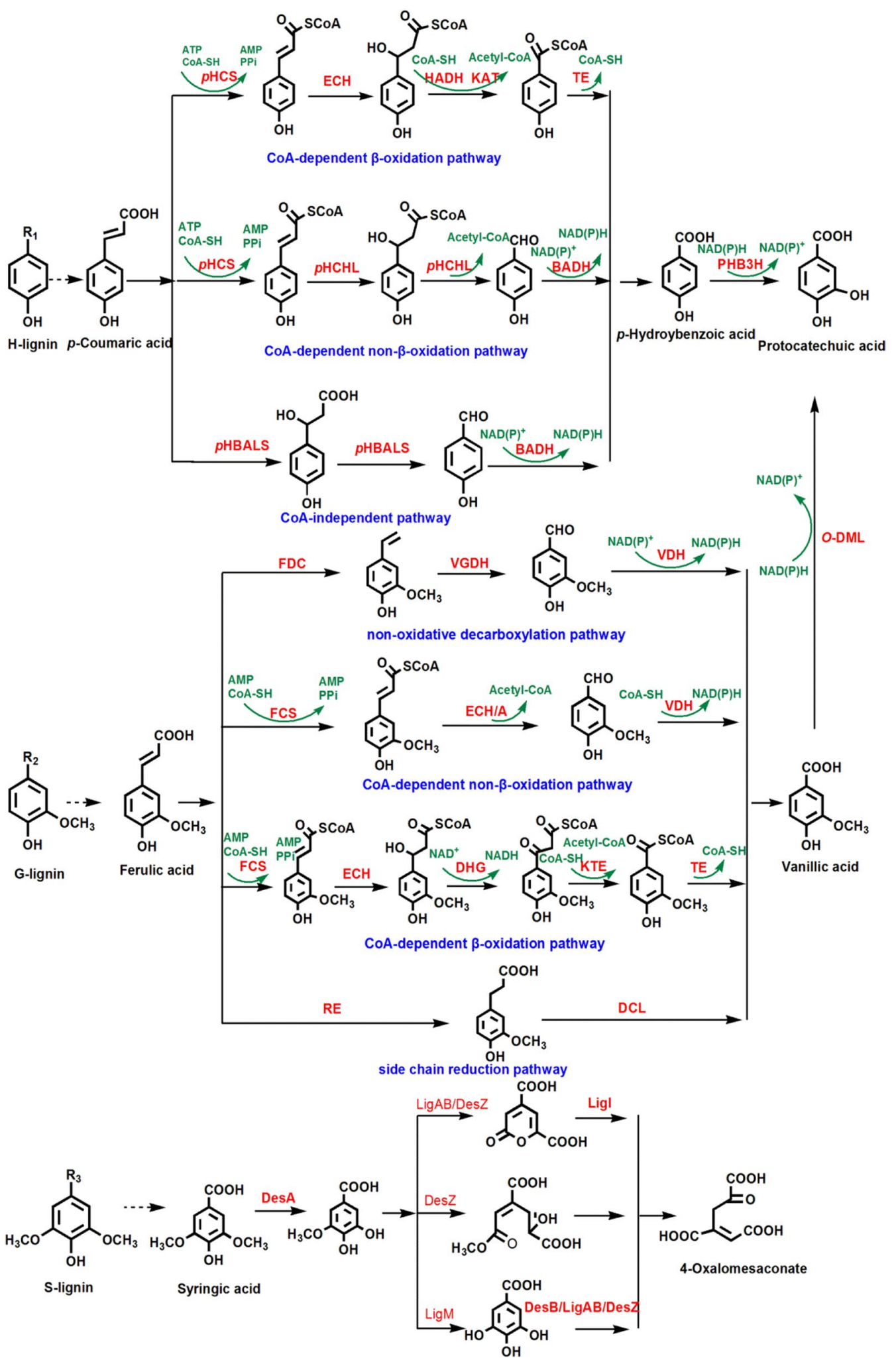


Finally, the vanillin dehydrogenase $(v d h)$ oxidizes vanillin to vanillic acid, which is further decomposed to protocatechuic acid by vanillate-O-demethylase (vanAB) [119]. The understanding of metabolic pathways in related strains will help to increase the yield of products from ferulic acid through metabolic engineering.

\section{Degradation of S-lignin-based derivatives}

The S-lignin-based derivatives (syringic acid) contain two methoxy groups in its aromatic ring, which makes them more difficult to be degraded than G- and $\mathrm{H}$-lignins. The S-lignin occupies $61.9 \%, 0,58.9 \%$, and $20.1 \%$ of the lignin in poplar, pine, corn, and Arabidopsis, respectively [110]. Compared with ferulic acid and $p$-coumaric acid, only a few microbes such as Sphingomonas sp. SYK-6 strain can metabolize syringic acid [120]. The demethylation of syringic acid is catalyzed to 3-O-methylgallate (3MGA) by tetrahydrofolate-dependent $O$-demethylase (DesA). The produced 3MGA can be converted to gallic acid (GA) and 4-carboxy-2-hydroxy-6-methoxy-6-oxohexa-2, 4-dienoate [120, 121], which are further transformed to 4-oxalomesaconate for acetyl-CoA synthesis. The intermediate 3MGA was then converted to 2-pyranone-4, 6-dicarboxylate, which is then converted to acetyl-CoA [122] (Fig. 6). Syringic acid was catalyzed to acetyl-CoA through multiple metabolic steps, which enters TCA cycle for cell growth and product synthesis. In addition to the typical lignin-derived aromatics, some aromatic compounds such as benzene, phenol, benzoate, toluene, and naphthalene can also be catalyzed to catechol [123].

\section{Degradation of protocatechuic acid and catechol}

Both protocatechuic acid and catechol are key intermediates in the metabolsim of lignin-based aromatic compounds. The dioxygenase enzymes exhibiting ortho (intradiol) or meta (extradiol) catalyze the aromatic ring cleavage of protocatechuic acid and catechol [120]. Catechol and protocatechuate are first transformed to cis, cis-muconate, and 3-carboxy-cis, cis-muconate through ortho-cleavage by $\mathrm{O}_{2}$-dependent dioxygenase. Muconates was converted to $\beta$-ketoadipate, which reacts with succinyl-CoA and form succinate and $\beta$-ketoadipyl-CoA [109]. The final product acetyl-CoA was produced from $\beta$-ketoadipyl-CoA and coenzyme A. The meta-cleavage pathways of catechol and protocatechuate are different due to the structural symmetry aspects. The meta-cleavage pathway of protocatechuate was classified into 2, 3 meta-cleavage and 4, 5 meta-cleavage. The 2-hydroxy5 -carboxymuconic semialdehyde was produced in the 2 , 3 meta-cleavage pathway of protocatechuate, and finally yield pyruvate and acetyl-CoA. The 2-hydroxy-4-carboxymuconic semialdehyde was produced from 4, 5 metacleavage of protocatechuate and eventually generate two pyruvate molecules [124] (Fig. 7). With the cleavage of aromatic ring, the produced intermediates succinate, acetyl-CoA, and pyruvate enter the central metabolism. In short, the metabolism of microorganisms for ligninbased compounds provides an platform for value-added bioproducts' synthesis.

\section{Bioconverting lignin to value-added bioproducts by microbial catalysis and metabolic engineering} In the traditional biomass refining process, the complex structure of lignin makes it difficult to be converted into high-value products like carbohydrates. With the elucidation of the structure of lignin and the microbial metabolism of lignin, it is possible to convert lignin into high value-added products through biological methods (Table 4).

\section{Lipids}

The demand for biofuel is expected to grow further due to the increasing global population and depleting fossil resources. Microorganisms can transform lignin to lipids as biofuel. Oleaginous microbes can generate high biomass with more than $20 \%$ lipids [125]. The metabolic route of lignin bioconversion to lipid includes four steps (Fig. 8): (1) degradation of low-molecular-weight lignin to its derivatives and other aromatics; (2) catabolism of the aromatic compounds to catechol or protocatechuate; (3) yield acetyl-CoA through aromatic ring cleavage and $\beta$-ketoadipate pathway; (4) lipid biosynthesis.

Rhodococcus species has been applied for converting lignin and aromatics to lipids; the 4-hydroxybenzoic acid and vanillic acid to triacylglycerols by $R$. opacus DSM 1069 and PD630 strains, which accumulated lipid about $20 \%$ of the dry cell weight (DCW) under nitrogenlimiting conditions [126]. $R$. rhodochrous could produce more lipids when cultivated with aromatic compounds and glucose [127]. The alkali, kraft, and ethanol organosolv lignin have also been applied for lipid production with bacteria catalysis. The alkali lignin $\left(4 \mathrm{~g} \mathrm{~L}^{-1}\right)$ could be degraded by $R$. pyridinivorans CCZUB16 with a lipid yield of 52\% [128]. The oxygen-pretreated kraft lignin was utilized by $R$. opacus DSM 1069 for lipid production, which was up to $14.21 \%$ of CDW and mainly include palmitic (46.9\%) and stearic (42.7\%) acids [129]. It was found that low-molecular-weight lignin compounds could be assimilated to form lipids more efficiently during the bacterial fermentation. Different strategies have been developed to reduce inhibition and increase lipids yield of microorganism with lignin as substrate. Laccase can synergize with $R$. opacus PD630 for lipid production with insoluble kraft lignin as substrate [130]. The co-fermentation of wild-type $R$. opacus PD630 and engineered $R$. jostii $\mathrm{RHA} \mathrm{VanA}^{-}$produces higher lipids than single 


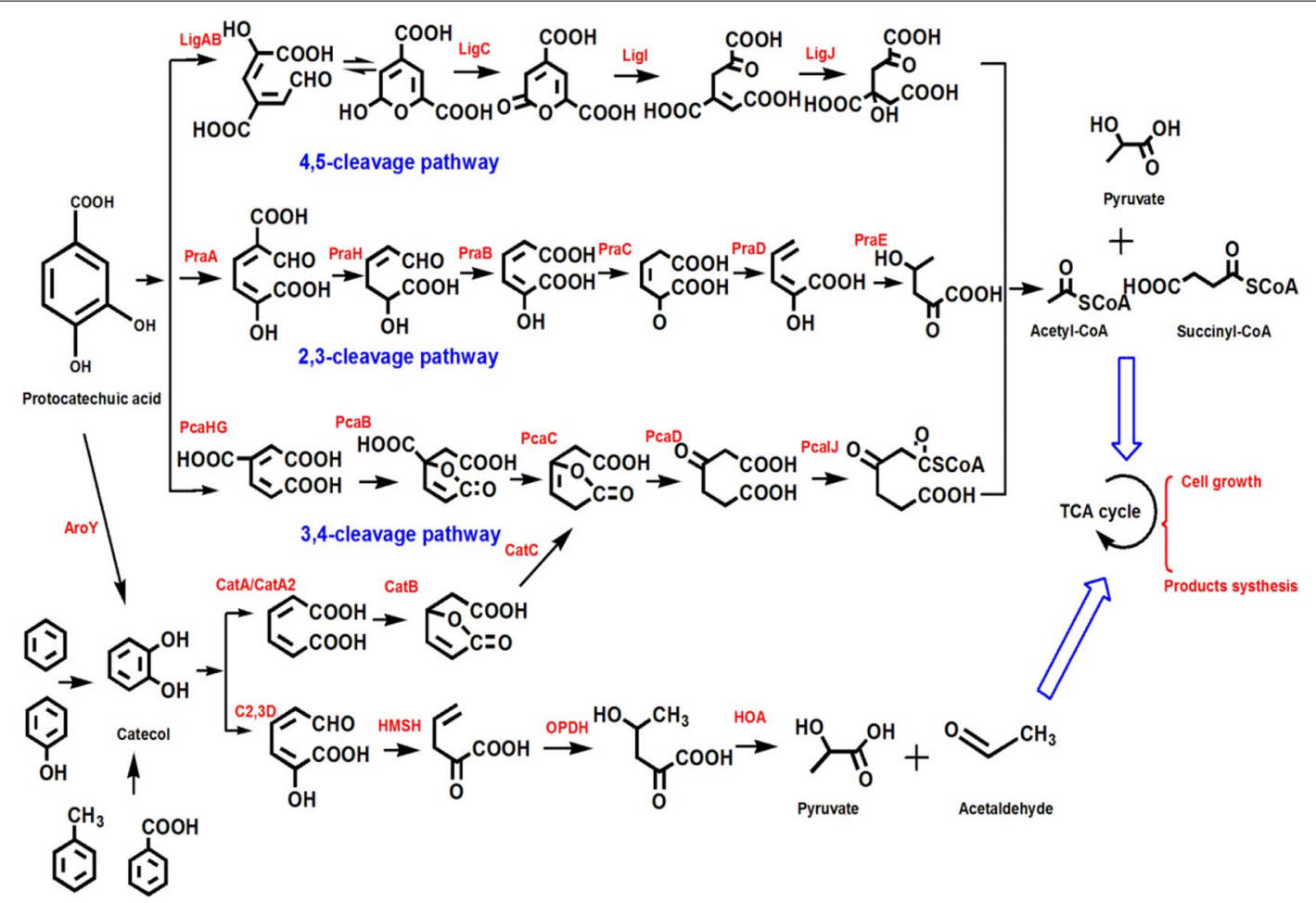

Fig. 7 The degradation of protocatechuic acid is categorized as 3, 4-cleavage pathway, 4, 5-cleavage pathway, and 2, 3-cleavage pathway. However, the degradation of catechol is mainly catalyzed by dioxygenases through ortho- or meta-cleavage pathway [120]. After completing aromatic ring cleavage, the molecules succinate, acetyl-CoA, and pyruvate enter the TCA cycle for cell growth and products' synthesis

strain fermentation [131]. The yeast Trichosporon cutaneum ACCC 20,271 was able to grow with 4-hydroxybenzaldehyde as the sole carbon source, and accumulate $0.85 \mathrm{~g} \mathrm{~L}^{-1}$ of lipid [132]. Lentinus tigrinus can accumulate $20 \%$ of lipid content in DCW using sunflower seed husks hydrolysates as substrate [133].

\section{Polyhydroxyalkanoates (PHAs)}

Polyhydroxyalkanoates (PHAs) are polyesters synthesized in cells as carbon and energy storage materials in granular forms by various microorganisms under nutrient imbalance conditions. With excellent biocompatibility and biodegradability, PHAs have been widely used in biomedicine, bioplastics, and nanotechnology [134, 135]. In nature, many bacteria have developed metabolic pathways for converting lignin to PHAs with short-, medium-, or long-chain length ( $\mathrm{scl}, \mathrm{mcl}$, and lcl). The lignin derivatives can be metabolized to acetyl-CoA for PHA synthesis (Fig. 8).

Currently, the PHA productions from lignin or ligninrelated aromatic compounds have been achieved in various bacteria. The aramatics of $p$-coumarate and ferulate can be converted to mcl-PHA by $P$. putida KT2440, and comparable mcl-PHA was also accumulated with APL as substrate [136]. The marine bacterium Oceanimonas doudoroffic can synthesize PHA from lignin and its derivatives such as sinapinic acid and syringic acid [137]. The untreated kraft lignin $\left(5 \mathrm{~g} \mathrm{~L}^{-1}\right)$ was converted to PHA (128 $\mathrm{mg} \mathrm{L}^{-1}$ ) by Cupriavidus basilensis B-8, and PHA concentration was up to $319.4 \mathrm{mg} \mathrm{L}^{-1}$ through fed batch fermentation [138]. System biology approach was developed to enhance PHA production from kraft lignin with P. putida A514, and the PHA content reached $73.5 \%$ (DCW), in which the dye peroxidase-based enzymatic system was optimized, and enzymes were overexpressed to promote central metabolism, and the $\beta$-oxidation of fatty acids were up-regulated to maximize carbon flux into PHA synthesis [139]. Besides improving the lignin utilization capability of related bacteria, lignin pretreatments were also applied to improve PHA production. $P$. putida KT2440 accumulate higher production of PHA from lignin pretreated with $\mathrm{H}_{2} \mathrm{SO}_{4}$ and $\mathrm{NaOH}$ [140]. The generated PHA can be converted to diverse chemicals precursors like alkenoic acids and hydrocarbons, which indicated that the lignin can be converted to biomaterials, chemical precursors, and fuel-range hydrocarbons.

\section{Vanillin}

As lignin has the unique aromatic structure, some valueadded intermediates can be accumulated in the process of 
Table 4 Bioconversion of lignin to value-added products by bacteria

\begin{tabular}{|c|c|c|c|c|}
\hline Products & Strains & Carbon source & Yield & Ref \\
\hline \multirow[t]{9}{*}{ Lipids } & Rhodococcus opacus DSM 43205 & Biomass gasification wastewater & $62.8 \%$ DCW & [159] (Goswami et al.) \\
\hline & R. pyridinivorans CCZUB16 & Alkali lignin & $52 \%$ DCW & [128] (Chong et al.) \\
\hline & R. opacus DSM 1069 & $\mathrm{O}_{2}$ pretreated kraft lignin & $14.21 \% \mathrm{DCW}$ & [129] (Wei et al.) \\
\hline & R. opacus PD630 & $\begin{array}{l}\text { Lignin from combinatorial pretreat- } \\
\text { ment }\end{array}$ & $1.83 \mathrm{~g} \mathrm{~L}^{-1}$ & [160] (Liu et al.) \\
\hline & R. opacus Xsp8 & Kraft lignin hydrolysate & $45.8 \%$ DCW & [153] (Kurosawa et al.) \\
\hline & $\begin{array}{l}\text { R. rhodochrous } \\
\text { ATCC } 2198\end{array}$ & $\begin{array}{l}\text { 4-Hydroxybenzoic acid, vanillic acid } \\
\text { and glucose }\end{array}$ & $>40 \%$ DCW & [127] (Shields-Menard et al.) \\
\hline & R. opacus DSM 1069 and PD630 & $\begin{array}{l}\text { 4-Hydroxybenzoic acid and vanillic } \\
\text { acid }\end{array}$ & $20 \%$ DCW & [126] (Kosa, Ragauskas) \\
\hline & $\begin{array}{l}\text { R. opacus PD630 and R. jostii RHA1 } \\
\text { VanA }^{-}\end{array}$ & Alkali-extracted corn stover lignin & $39 \%$ DCW & [131] (He et al.) \\
\hline & Trichosporon cutaneum ACCC 20271 & 4-hydroxybenzaldehyde & $0.85 \mathrm{~g} \mathrm{~L}^{-1}$ & [132] (Hu et al.) \\
\hline \multirow[t]{6}{*}{ PHAs } & Pseudomonas putida KT2440 & Alkaline-pretreated liquor & $34-39 \%$ DCW & [136] (Linger et al.) \\
\hline & Ralstonia eutropha & Bagasse hydrolyssate & $6.06 \mathrm{~g} \mathrm{~L}^{-1}$ & [161] (Yu, Stahl) \\
\hline & Azotobacter beijerinicki & Coir pith & $2.4 \mathrm{~g} \mathrm{~L}^{-1}$ & [162] (Prabu, Murugesan) \\
\hline & Engineered P.putida A514 & Kraft lignin & $75 \mathrm{mg} \mathrm{L}^{-1}$ & [139] (Wang et al.) \\
\hline & Oceanimonas doudoroffii & Lignin and its derivatives & $0.2 \% \mathrm{DCW}$ & [137] (Numata, Morisaki) \\
\hline & Cupriavidus basilensis B-8 & Kraft lignin & $319.4 \mathrm{mg} \mathrm{L}^{-1}$ & [138] (Shi et al.) \\
\hline \multirow[t]{5}{*}{ Vanillin } & R. jostii RHA045 & Wheat straw lignocellulose & $96 \mathrm{mg} \mathrm{L}^{-1}$ & [53] (Sainsbury et al.) \\
\hline & Bacillus subtilis & Ferulic acid & $0.89 \mathrm{~g} \mathrm{~L}^{-1}$ & [143] (Chen et al.) \\
\hline & Streptomyces sannanensis MTCC 6637 & Wheat bran & $0.708 \mathrm{~g} \mathrm{~L}^{-1}$ & [163] (Chattopadhyay et al.) \\
\hline & Shewanella putrefaciens & Lignin extracted from wheat straw & $275 \mathrm{mg} \mathrm{L}^{-1}$ & [142] (Sharma et al.) \\
\hline & Engineered P. putida KT2440 & Ferulic acid & $0.86 \mathrm{~g} \mathrm{~g}^{-1}$ & [119] (Graf, Altenbuchner) \\
\hline \multirow[t]{5}{*}{ Cis,cis-muconate } & P. putida KT2440-CJ242 & p-Coumaric acid & $50 \mathrm{~g} \mathrm{~L}^{-1}$ & [142] (Sharma et al.) \\
\hline & Recombinant C. glutamicum MA-2 & Lignin hydrolysate and Catechol & $1.8 \mathrm{~g} \mathrm{~L}^{-1}$ and $85 \mathrm{~g} \mathrm{~L}^{-1}$ & [22] (Becker et al.) \\
\hline & Recombinant E. coli & Catechol & $59.0 \mathrm{~g} \mathrm{~L}^{-1}$ & [149] (Kaneko et al.) \\
\hline & P. putida MA-9 & Softwood lignin hydrolysate & $13 \mathrm{~g} \mathrm{~L}^{-1}$ & [164] (Kohlstedt et al.) \\
\hline & Sphingobium sp. SME257/pTS084 & Hardwood lignin hydrolysate & $26.8 \mathrm{mg} \mathrm{L}^{-1}$ & [165] (Sonoki et al.) \\
\hline
\end{tabular}

lignin degradation and metabolism. Vanillin (4-hydroxy3-methoxybenzaldehyde) is one of the most important aromatic compounds and has been widely applied to food, cosmetics, pharmaceutical, and other industries [141]. Vanillin is usually extracted from natural plant or synthesis through chemical synthesis, and biosynthesis of vanillin with lignin as a feedstock is a clean and promising method. In the metabolic process of lignin, vanillin can be released from lignin through depolymerization or produced from ferulic acid through microbial catalysis (Fig. 8). A microbial fuel cell system was designed for depolymerizing lignin and produces vanillin through $\mathrm{H}_{2} \mathrm{O}_{2}$-mediated oxidative reaction [142]. Vanillin can be produced from ferulic acid with Bacillus subtilis, Streptomyces sp., and Amycolatopsis sp. [143].

Metabolic engineering has been developed to improve the yield of vanillin in microorganisms. It has been reported that vanillin accumulation in Amycolatopsis sp. ACTT 39,116 was achieved by the deletion of $v d h$ gene, which encodes NAD-dependent vanillin dehydrogenase for converting vanillin to vanillic acid, and the mutant strain produced $6.5 \mathrm{mM}$ vanillin with $2 \mathrm{mM}$ ferulic acid as substrate [144]. P. putida KT2440 was optimized to convert $86 \%$ of ferulic acid to vanillin with low by-product, in which strong tac promoter was applied to enhance the expression of $f c s$ and ech [117]. With excellent antimicrobial, antioxidant properties, and low toxicity, $p$-hydroxybenzoic acid and pyrogallol are produced from lignin and its derivative $[145,146]$.

\section{Cis, cis-muconate (cis, cis-MA)}

Cis, cis-muconate (cis, cis-MA) is a six-carbon di-unsaturated dicarboxylic acid and a direct precursor for adipic acid and terephthalic acid, which are mainly used to produce polymers including nylon, polyurethane, and polyethylene terephthalate (PET) [147]. Cis, cis-MA has been conventionally produced through chemical synthesis using petroleum-based feedstocks and generating toxic intermediates. Therefore, production of cis, cis-MA from lignocellulosic biomass provides a feasible alternative 


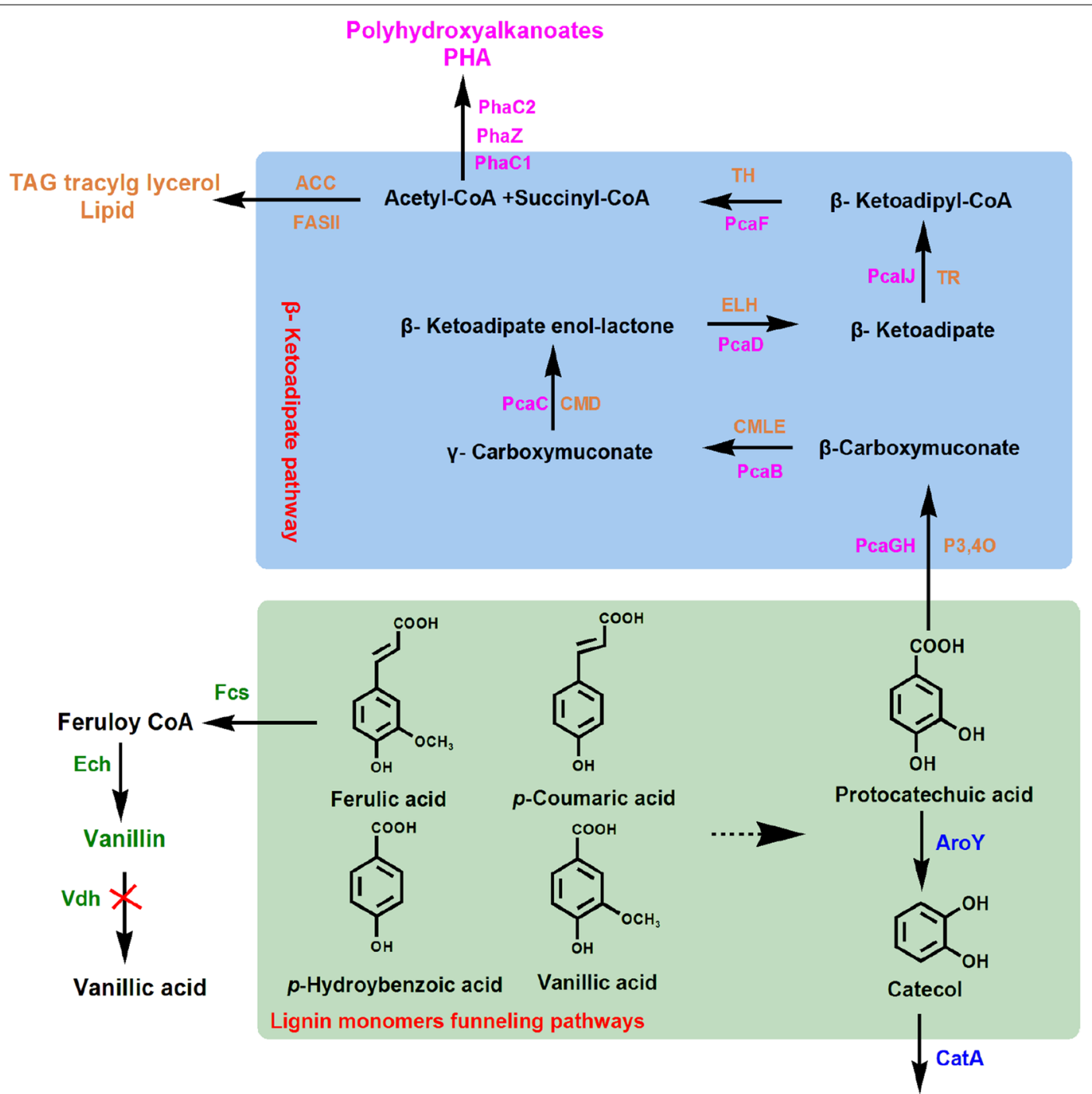

\section{Cis,cis-muconate

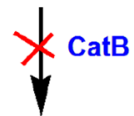 \\ Muconolactone}

Fig. 8 Simple metabolic route for producing valuable compounds from lignin-derived aromatics. Lignin monomers are converted to acetyl-CoA as a final intermediate of protocatechuate metabolism in $\beta$-ketoadipate pathway. Lipid and polyhydroxyalkanoates are generated from the significant intermediate of acetyl-CoA via natural catabolic pathways in Rhodococci opacus (pink) and Pseudomonas putida KT2440 (orange), respectively [58, 126]. Rhodococcus sp. RHA1 is engineered to accumulate a significant amount of vanillin from feruilic acid by deleting vanillin dehydrogenase (Vdh) gene (green). Cis, cis-muconate has been proved to improve its yield in the engineered strain of $P$. putida by deletion of muconate cycloisomerase (CatB) gene and insertion of protocatechuate decarboxylase (AroY) gene (blue) [59]

strategy to alleviate the environmental issues in chemical synthesis. Lignin-based aromatics was converted to cis, cis-MA by microbial catalysis, which is a crucial intermediate of aromatics metabolism. The cis, cis-MA was accumulated and secreted into the culture broth when its degradation route was disrupted (Fig. 8). The engineered strains such as P. putida, Amycolatopsis sp, E. coli, and Corynebacterium glutamicum have been reported to produce high MA yields from lignin-based aromatics. The production of cis, cis-MA from $p$-coumaric acid with the engineered P. putida KT2440 reached $50 \mathrm{~g} \mathrm{~L}^{-1}$, in which two associated proteins (EcdBD) were co-expressed and 
a global regulator of carbon catabolite repression was eliminated [148]. Becker et al. [22] engineered the C. glutamicum MA-2 strain with the elimination of muconate cycloisomerase (catB) and overexpression of catechol-1 and 2-dioxygenase (catA), which produces respective $85 \mathrm{~g}$ $\mathrm{L}^{-1}$ and $1.8 \mathrm{~g} \mathrm{~L}^{-1}$ cis, cis-MA from catechol and hydrothermal pretreated softwood lignin. Similar E. coli was constructed by expressing the catA gene from $P$. putida $\mathrm{mt}-2$ and produced $59 \mathrm{~g} \mathrm{~L}^{-1}$ cis, cis-MA from catechol with a molar yield of $100 \%$ in a fed-batch fermentation [149].

The dicarboxylic acids like pyridine-2, 4-dicarboxylic acid (2, 4-PDCA) and pyridine-2, 5-dicarboxylic acid (2, 5-PDCA) can also be produced from lignin and serve as building blocks for polyamides and polyesters [150]. The bacterium $R$. jostii RHA1 metabolize lignin through the $\beta$-ketoadipate pathway. The metabolic pathways of $R$. jostii RHA1 were engineered by insertion of genes ligABencoding protocatechuate 4,5-dioxygenase and protocatechuate 2,3-dioxygenase, and $80 \mathrm{mg} \mathrm{L}^{-1}$ 2,4-PDCA and $125 \mathrm{mg} \mathrm{L}^{-1} 2,5$-PDCA were produced when cultured on minimal media containing $1 \%$ wheat straw lignocellulose [54].

\section{Conclusions}

Lignin is the most abundant aromatic biopolymer in nature and an excellent substrate for value-added bioproducts synthesis. Bioprocessing with microorganisms and enzymes is a clean and efficient method for lignin utilization, while the low efficiency of lignin valorization is a challenge in the process. The pretreatment can break lignin to small fragments, which can improve the bioavailability of which to microorganisms [151]. The oxidase secreted by microorganims are crucial for lignin degradation, which has been applied to improve lignin the bioavailability and depolymerization in vitro [152]. The cell growth inhibition by lignin-derived aromatics is another issue in lignin bioprocessing and utilization. The strategies including microorganisms acclimation and fed-batch operation have been applied to mitigate the inhibitory effects of aromatic compounds [153]. The elucidation of the pathway for lignin degradation and metabolism and its aromatic compounds provide an platform for lignin depolymerization and biotransformation into valueadded products through metabolic engineering. Further research on microbial metabolic engineering and industrial process scale-up are still required to realize the efficient lignin depolymerization and value-added products' biosynthesis.

\section{Abbreviations}

MnP: Manganese peroxidase; LiP: Lignin peroxidase; VP: Versatile peroxidase; DyP: Dye-decolorizing peroxidase; TCA: Tricarboxylic acid cycle; PPO:
Polyphenol oxidase; $\mathrm{H}_{2} \mathrm{O}_{2}$ : Hydrogen peroxide; APL: Alkaline pretreated liquor; $\mathrm{NAD}(\mathrm{P}) \mathrm{H}$ : Nicotinamide adenine dinucleotide phosphate; ATP: Adenosine triphosphate; ABTS: 2,2'-Azinobis-(3-ethylbenzothiazoline-6-sulfonate); HAA: 3-Hydroxyanthranilic acid; HBT: 1-Hydroxybenzotriazole; VA: Veratryl alcohol; GS-HPV: a-Glutathionyl- $\beta$-hydroxypropiovanillone; PCB: Polychlorinated biphenyls; DDVA: 5, 5'-Dehydrodivanillate; 5CVA: 5-Carboxyvanillic acid; pHCS: $p$-Hydroxycinnamoyl CoA synthetase; pHCHL: $p$-Hydroxycinnamoyl CoA hydratase/lyase; BADH: Benzaldehyde dehydrogenase; fcs: Feruloyl-CoA synthetase; ech: Enoyl-CoA hydratase/aldolase; vdh: Vanillin dehydrogenase; vanAB: Vanillate-O-demethylase; 3MGA: 3-O-Methylgallate; DesA: Tetrahydrofolate-dependent O-demethylase; GA: Gallic acid; DCW: Dry cell weight; PHAs: Polyhydroxyalkanoates; cis, cis-MA: cis, cis-Muconate; PET: Polyethylene terephthalate; catB: Muconate cycloisomerase; catA: Catechol-1,2-dioxygenase; 2,4PDCA: Pyridine-2,4-dicarboxylic acid; 2,5-PDCA: Pyridine-2,5-dicarboxylic acid.

\section{Acknowledgements}

The work was supported by the National Key Research and Development Project China (No.SQ2019YFB150055) and the Key Research Program of Nanjing IPE Institute of Green Manufacturing Industry (E0010716).

\section{Authors' contributions}

Y. H. and C.W. conceived the idea for the review. C.W. and Y. H. performed the literature research and writing; Y. H. and X. P. revised the manuscript. All authors read and approved the final manuscript.

\section{Funding}

The National Key Research and Development Project China (No. SQ2019YFB150055) and the Key Research Program of Nanjing IPE Institute of Green Manufacturing Industry (E0010716).

Availability of data and materials

Not applicable.

\section{Declarations}

Ethics approval and consent to participate

Not applicable.

\section{Consent for publication}

All authors read and approved the final manuscript for publication.

\section{Competing interests}

The authors declare that they have no competing financial interests.

\section{Author details}

${ }^{1}$ National Key Laboratory of Biochemical Engineering, Institute of Process Engineering, Chinese Academy of Sciences, Beijing 100190, China. ${ }^{2}$ School of Chemical Engineering, University of Chinese Academy of Sciences, Beijing 100049, China.

Received: 5 January 2021 Accepted: 19 March 2021

Published online: 03 April 2021

References

1. Chauhan PS. Role of various bacterial enzymes in complete depolymerization of lignin: a review. Biocatal Agric Biotechnol. 2020;23:101498. https://doi.org/10.1016/j.bcab.2020.101498.

2. Peng X, Qiao W, Mi S, Jia X, Su H, Han Y. Characterization of hemicellulase and cellulase from the extremely thermophilic bacterium Caldicellulosiruptor owensensis and their potential application for bioconversion of lignocellulosic biomass without pretreatment. Biotechnol Biofuels. 2015;8:131. https://doi.org/10.1002/bit.26578.

3. Peng X, Su H, Mi S, Han Y. A multifunctional thermophilic glycoside hydrolase from Caldicellulosiruptor owensensis with potential applications in production of biofuels and biochemicals. Biotechnol Biofuels. 2016;9:98. https://doi.org/10.1186/s13068-016-0509-y.

4. Han Y, Dodd D, Hespen CW, Ohene-Adjei S, Schroeder CM, Mackie RI, et al. Comparative analyses of two thermophilic enzymes exhibiting 
both $\beta-1,4$ mannosidic and $\beta-1,4$ glucosidic cleavage activities from Caldanaerobius polysaccharolyticus. J Bacteriol. 2010;192:4111-21. https://doi.org/10.1128/JB.00257-10.

5. Han Y, Agarwal V, Dodd D, Kim J, Bae B, Mackie RI, et al. Biochemical and structural insights into xylan utilization by the thermophilic bacterium Caldanaerobius polysaccharolyticus. J Biol Chem. 2012;287:34946-60. https://doi.org/10.1074/jbc.M112.391532.

6. Peng X, Li C, Liu J, Yi Z, Han Y. Changes in composition, cellulose degradability and biochemical methane potential of Miscanthus species during the growing season. Bioresour Technol. 2017;235:389-95. https:// doi.org/10.1016/j.biortech.2017.03.128.

7. Chen $\mathrm{H}, \mathrm{Han} \mathrm{Y}, \mathrm{Xu}$ J. Simultaneous saccharification and fermentation of steam exploded wheat straw pretreated with alkaline peroxide. Process Biochem. 2008:43:1462-6. https://doi.org/10.1016/j.procbio.2008.07. 003.

8. Abdelaziz OY, Brink DP, Prothmann J, Ravi K, Sun M, Garcia-Hidalgo J, et al. Biological valorization of low molecular weight lignin. Biotechnol Adv. 2016;34:1318-46. https://doi.org/10.1016/j.biotechadv.2016.10. 001.

9. Zakzeski J. The catalytic valorization of lignin for the production of renewable chemicals. Chem Rev. 2010;110:3552-99. https://doi.org/10. 1021/cr900354u.

10. Vanholme R, Demedts B, Morreel K, Ralph J, Boerjan W. Lignin biosynthesis and structure. Plant Physiol. 2010;153:895-905. https://doi.org/ 10.1104/pp.110.155119.

11. Bandounas L. Isolation and characterization of novel bacterial strains exhibiting ligninolytic potential. BMC Biotechnol. 2011;11:94. https:// doi.org/10.1186/1472-6750-11-94.

12. Chen Z, Wan C. Biological valorization strategies for converting lignin into fuels and chemicals. Renew Sust Energ Rev. 2017;73:610-21. https://doi.org/10.1016/.rser.2017.01.166.

13. Kamimura N, Sakamoto S, Mitsuda N, Masai E, Kajita S. Advances in microbial lignin degradation and its applications. Curr Opin Biotechnol. 2019;56:179-86. https://doi.org/10.1016/j.copbio.2018.11.011.

14. de Gonzalo G, Colpa DI, Habib MH, Fraaije MW. Bacterial enzymes involved in lignin degradation. J Biotechnol. 2016;236:1 10-9. https:// doi.org/10.1016/j.jbiotec.2016.08.011.

15. Kirk TK, Cullen D. Enzymology and molecular genetics of wood degradation by white-rot fungi. In: Akhtar M, Young RA, editors. Environmentally friendly technologies for the pulp and paper industry. Wiley; 1997.

16. Kamimura N, Takahashi K, Mori K, Araki T, Fujita M, Higuchi Y, et al. Bacterial catabolism of lignin-derived aromatics: new findings in a recent decade: update on bacterial lignin catabolism. Environ Microbiol Rep. 2017:9:679-705. https://doi.org/10.1111/1758-2229.12597.

17. Tomizawa S, Chuah J-A, Matsumoto K, Doi Y, Numata K. Understanding the limitations in the biosynthesis of polyhydroxyalkanoate (PHA) from lignin derivatives. ACS Sustain Chem Eng. 2014;2:1106-13. https://doi. org/10.1021/sc500066f

18. Chatterjee A, DeLorenzo DM, Carr R, Moon TS. Bioconversion of renewable feedstocks by Rhodococcus opacus. Curr Opin Biotechnol. 2019;64:10-6. https://doi.org/10.1016/j.copbio.2019.08.013.

19. Doherty WOS, Mousavioun P, Fellows CM. Value-adding to cellulosic ethanol: lignin polymers. Ind Crop Prod. 2011;33(2):259-76. https://doi. org/10.1016/j.indcrop.2010.10.022

20. Turan V, Schroder P, Bilen S, Insam H, Juarez MFD. Co-inoculation effect of Rhizobium and Achillea millefolium L. oil extracts on growth of common bean (Phaseolus vulgaris $\mathrm{L}$. and soil microbial-chemical properties. Sci Rep. 2019;9:15178. https://doi.org/10.1038/s41598-019-51587-x.

21. Klammsteiner T, Turan $V$, Fernandez-Delgado Juarez $M$, Oberegger $S$, Insam H. Suitability of black soldier fly frass as soil amendment and implication for organic waste hygienization. Agronomy. 2020;10:1578. https://doi.org/10.3390/agronomy10101578.

22. Harshvardhan K, Suri M, Goswami A, Goswami T. Biological approach for the production of vanillin from lignocellulosic biomass (Bambusa tulda). J Clean Prod. 2017;149:485-90. https://doi.org/10.1016/j.jclepro.2017. 02.125 .

23. Becker J, Kuhl M, Kohlstedt M, Starck S, Wittmann C. Metabolic engineering of Corynebacterium glutamicum for the production of cis, cis-muconic acid from lignin. Microb Cell Fact. 2018;17:115. https:// doi.org/10.1186/s12934-018-0963-2.
24. Brown ME, Chang MC. Exploring bacterial lignin degradation. Curr Opin Chem Biol. 2014;19:1-7. https://doi.org/10.1016/j.cbpa.2013.11. 015.

25. Andlar M, Rezic T, Mardetko N, Kracher D, Ludwig R, Santek B. Lignocellulose degradation: an overview of fungi and fungal enzymes involved in lignocellulose degradation. Eng Life Sci. 2018;18:768-78. https://doi.org/10.1002/elsc.201800039.

26. Blanchette RA. Degradation of the lignocellulose complex in wood. Can J Bot. 1995;73:999

27. Sigoillot J-C, Berrin J-G, Bey M, Lesage-Meessen L, Levasseur A, Lomascolo A, et al. Fungal strategies for lignin degradation. Adv Bot Res. 2012;61:263-308. https://doi.org/10.1016/B978-0-12-416023-1. 00008-2.

28. Wong DW. Structure and action mechanism of ligninolytic enzymes. Appl Biochem Biotechnol. 2009;157:174-209. https://doi.org/10.1007/ s12010-008-8279-z.

29. Abdel-Hamid AM, Solbiati JO, Cann IK. Insights into lignin degradation and its potential industrial applications. Adv Appl Microbiol. 2013;82:128. https://doi.org/10.1016/B978-0-12-407679-2.00001-6.

30. Zabel RA, Morrell JJ. Wood microbiology decay and its prevention. 2nd ed. Elsevier Inc; 2020. https://doi.org/10.1016/C2018-0-05117-8.

31. Singh D, Zeng J, Laskar DD, Deobald L, Hiscox WC, Chen S. Investigation of wheat straw biodegradation by Phanerochaete chrysosporium. Biomass Bioenergy. 2011;35:1030-40. https://doi.org/10.1016/j.biomb ioe.2010.11.021.

32. Zhao L, Cao GL, Wang AJ, Ren HY, Dong D, Liu ZN, et al. Fungal pretreatment of cornstalk with Phanerochaete chrysosporium for enhancing enzymatic saccharification and hydrogen production. Bioresour Technol. 2012;114:365-9. https://doi.org/10.1016/j.biortech.2012.03.076.

33. Zeng G-M, Zhao M-H, Huang D-L, Lai C, Huang C, Wei Z, et al. Purification and biochemical characterization of two extracellular peroxidases from Phanerochaete chrysosporium responsible for lignin biodegradation. Int Biodeterior Biodegrad. 2013;85:166-72. https://doi.org/10. 1016/j.ibiod.2013.07.005.

34. Dong XQ, Yang JS, Zhu N, Wang ET, Yuan HL. Sugarcane bagasse degradation and characterization of three white-rot fungi. Bioresour Technol. 2013;131:443-51. https://doi.org/10.1016/j.biortech.2012.12.182.

35. Kamei I, Hirota Y, Meguro S. Integrated delignification and simultaneous saccharification and fermentation of hard wood by a white-rot fungus, Phlebia sp. MG-60. Bioresour Technol. 2012;126:137-41. https://doi.org/ 10.1016/j.biortech.2012.09.007.

36. Guerra A, Mendonca R, Ferraz A, Lu F, Ralph J. Structural characterization of lignin during Pinus taeda wood treatment with Ceriporiopsis subvermispora. Appl Environ Microbiol. 2004;70:4073-8. https://doi.org/ 10.1128/AEM.70.7.4073-4078.2004.

37. Jin W, Li J, Feng H, You S, Zhang L, Norvienyeku J, et al. Importance of a laccase gene (LCCI) in the development of Ganoderma tsugae. Int J Mol Sci. 2018. https://doi.org/10.3390/ijms19020471.

38. Reddy C. The potential for white-rot fungi in the treatment of pollutants. Curr Opin Biotechnol. 1995;6:320-8. https://doi.org/10.1016/09581669(95)80054-9.

39. Asgher M, Bhatti HN, Ashraf M, Legge RL. Recent developments in biodegradation of industrial pollutants by white rot fungi and their enzyme system. Biodegradation. 2008;19:771-83. https://doi.org/10. 1007/s10532-008-9185-3.

40. Bugg TD, Ahmad M, Hardiman EM, Rahmanpour R. Pathways for degradation of lignin in bacteria and fungi. Nat Prod Rep. 2011;28:1883-96. https://doi.org/10.1039/c1np00042j.

41. Jensen KA Jr, Houtman CJ, Ryan ZC, Hammel KE. Pathways for extracellular Fenton chemistry in the brown rot basidiomycete Gloeophyllum trabeum. Appl Environ Microbiol. 2001;67:2705-11. https://doi.org/10. 1128/AEM.67.6.2705-2711.2001.

42. Yelle DJ, Ralph J, Lu F, Hammel KE. Evidence for cleavage of lignin by a brown rot basidiomycete. Environ Microbiol. 2008;10:1844-9. https:// doi.org/10.1111/j.1462-2920.2008.01605.x.

43. Yelle DJ, Wei D, Ralph J, Hammel KE. Multidimensional NMR analysis reveals truncated lignin structures in wood decayed by the brown rot basidiomycete Postia placenta. Environ Microbiol. 2011;13:1091-10100. https://doi.org/10.1111/j.1462-2920.2010.02417.x. 
44. Knežević A, Milovanović I, Stajić M, Lončar N, Brčeski I, Vukojević J, et al. Lignin degradation by selected fungal species. Bioresour Technol. 2013;138:117-23. https://doi.org/10.1016/j.biortech.2013.03.182.

45. Kuhad RC. Microorganisms and enzymes involved in the degradation of plant fiber cell walls. Adv Biochem Eng Biotechnol. 1997;57:47-125.

46. Hamed SAM. In-vitro studies on wood degradation in soil by soft-rot fungi: Aspergillus niger and Penicillium chrysogenum. Int Biodeterior Biodegrad. 2013;78:98-102. https://doi.org/10.1016/j.ibiod.2012.12.013.

47. Aarti MVA, Agastian P. Lignin degradation: a microbial approach. South Indian J Biol Sci. 2015;1:119-27. https://doi.org/10.22205/sijbs/2015/v1/ i3/100405.

48. Xu R, Zhang K, Liu P, Han H, Zhao S, Kakade A, et al. Lignin depolymerization and utilization by bacteria. Bioresour Technol. 2018;269:557-66. https://doi.org/10.1016/j.biortech.2018.08.118.

49. Bugg TD, Ahmad M, Hardiman EM, Singh R. The emerging role for bacteria in lignin degradation and bio-product formation. Curr Opin Biotechnol. 2011;22:394-400. https://doi.org/10.1016/j.copbio.2010.10. 009.

50. Zimmermann W. Degradation of lignin by bacteria. J Biotechnol. 1990;13:119-30. https://doi.org/10.1016/0168-1656(90)90098-V.

51. Zeng J, Singh D, Laskar DD, Chen S. Degradation of native wheat straw lignin by Streptomyces viridosporus T7A. Int J Environ Sci Technol. 2012;10:165-74. https://doi.org/10.1007/s13762-012-0085-z.

52. ANTAl. Degradation of softwood, hardwood, and grass lignocelluloses by two streptomyces strains. Appl Environ Microbiol. 1981;42:378-80. https://doi.org/10.1128/AEM.42.2.378-380.

53. Sainsbury PD, Hardiman EM, Ahmad M, Otani H, Seghezzi N, Eltis LD, et al. Breaking down lignin to high-value chemicals: the conversion of lignocellulose to vanillin in a gene deletion mutant of Rhodococcus jostii RHA1. ACS Chem Biol. 2013;8:2151-6. https://doi.org/10.1021/ cb400505a.

54. Mycroft Z, Gomis M, Mines P, Law P, Bugg TDH. Biocatalytic conversion of lignin to aromatic dicarboxylic acids in Rhodococcus jostii RHA1 by rerouting aromatic degradation pathways. Green Chem. 2015;17:4974-9. https://doi.org/10.1039/x0xx00000x.

55. Salvachúa D, Werner AZ, Pardo I, Michalska M, Black BA, Donohoe BS, et al. Outer membrane vesicles catabolize lignin-derived aromatic compounds in Pseudomonas putida KT2440. Proc Natl Acad Sci U S A. 2020;117:9302-10. https://doi.org/10.1073/pnas.1921073117.

56. Ahmad M, Roberts JN, Hardiman EM, Singh R, Eltis LD, Bugg TD. Identification of DypB from Rhodococcus jostii RHA1 as a lignin peroxidase. Biochemistry. 2011;50:5096-107. https://doi.org/10.1021/bi101892z.

57. Taylor CR, Hardiman EM, Ahmad M, Sainsbury PD, Norris PR, Bugg TD. Isolation of bacterial strains able to metabolize lignin from screening of environmental samples. J Appl Microbiol. 2012;113:521-30. https://doi. org/10.1111/j.1365-2672.2012.05352.x.

58. Salvachúa D, Karp EM, Nimlos CT, Vardon DR, Beckham GT. Towards lignin consolidated bioprocessing: simultaneous lignin depolymerization and product generation by bacteria. Green Chem. 2015;17:495167. https://doi.org/10.1039/c5gc01165e.

59. Xu Z, Qin L, Cai M, Hua W, Jin M. Biodegradation of kraft lignin by newly isolated Klebsiella pneumoniae, Pseudomonas putida, and Ochrobactrum tritici strains. Environ Sci Pollut Res Int. 2018;25:14171-81. https://doi. org/10.1007/s11356-018-1633-y.

60. Shi Y, Chai L, Tang $C$, Yang Z, Zheng Y, Chen Y, et al. Biochemical investigation of kraft lignin degradation by Pandoraea sp. B-6 isolated from bamboo slips. Bioprocess Biosyst Eng. 2013;36:1957-65. https://doi.org/ 10.1007/s00449-013-0972-9.

61. Chai LY, Chen YH, Tang CJ, Yang ZH, Zheng Y, Shi Y. Depolymerization and decolorization of kraft lignin by bacterium Comamonas sp. B-9. Appl Microbiol Biotechnol. 2014;98:1907-12. https://doi.org/10.1007/ s00253-013-5166-5.

62. Zhu D, Zhang P, Xie C, Zhang W, Sun J, Qian WJ, et al. Biodegradation of alkaline lignin by Bacillus ligniniphilus L1. Biotechnol Biofuels. 2017;10:44. https://doi.org/10.1186/s13068-017-0735-y.

63. Mei J, Shen X, Gang L, Xu H, Wu F, Sheng L. A novel lignin degradation bacteria-Bacillus amyloliquefaciens SL-7 used to degrade straw lignin efficiently. Bioresour Technol. 2020;310:123445. https://doi.org/10. 1016/j.biortech.2020.123445.

64. Ahring BK, Biswas R, Ahamed A, Teller PJ, Uellendahl H. Making lignin accessible for anaerobic digestion by wet-explosion pretreatment.
Bioresour Technol. 2015;175:182-8. https://doi.org/10.1016/j.biortech. 2014.10.082.

65. Khan MU, Ahring BK. Lignin degradation under anaerobic digestion: Influence of lignin modifications-a review. Biomass Bioenergy. 2019;128:105325. https://doi.org/10.1016/j.biombioe.2019.105325.

66. Kato S, Chino K, Kamimura N, Masai E, Yumoto I, Kamagata Y. Methanogenic degradation of lignin-derived monoaromatic compounds by microbial enrichments from rice paddy field soil. Sci Rep. 2015;5:14295. https://doi.org/10.1038/srep14295.

67. Deangelis KM, D'Haeseleer P, Chivian D, Fortney JL, Khudyakov J, Simmons B, et al. Complete genome sequence of Enterobacter lignolyticus SCF1. Stand Genomic Sci. 2011;5:69-85. https://doi.org/10.4056/sigs. 2104875.

68. Deangelis KM, Sharma D, Varney R, Simmons B, Isern NG, Markilllie LM, et al. Evidence supporting dissimilatory and assimilatory lignin degradation in Enterobacter lignolyticus SCF1. Front Microbiol. 2013;4:280. https://doi.org/10.3389/fmicb.2013.00280.

69. Woo HL. Complete genome sequence of the lignindegrading bacterium Klebsiella sp. strain BRL6-2. Stand Genomic Sci. 2014;9:19. https:// doi.org/10.1186/1944-3277-9-19.

70. Billings AF, Fortney JL, Hazen TC, Simmons B, Davenport KW, Goodwin $L$, et al. Genome sequence and description of the anaerobic lignindegrading bacterium Tolumonas lignolytica sp. nov. Stand Genomic Sci. 2015;10:106. https://doi.org/10.1186/s40793-015-0100-3.

71. Duan J, Huo X, Du WJ, Liang JD, Wang DQ, Yang SC. Biodegradation of kraft lignin by a newly isolated anaerobic bacterial strain, Acetoanaerobium sp. WJDL-Y2. Lett Appl Microbiol. 2016;62:55-62. https://doi.org/ 10.1111/lam.12508.

72. Rahmanpour R, Rea D, Jamshidi S, Fülöp V, Bugg TD. Structure of Thermobifida fusca DyP-type peroxidase and activity towards kraft lignin and lignin model compounds. Arch Biochem Biophys. 2016;594:54-60. https://doi.org/10.1016/j.abb.2016.02.019.

73. Akinosho HO, Yoo CG, Dumitrache A, Natzke J, Muchero W, Brown $\mathrm{SD}$, et al. Elucidating the structural changes to populus lignin during consolidated bioprocessing with Clostridium thermocellum. ACS Sustain Chem Eng. 2017;5:7486-91. https://doi.org/10.1021/acssuschemeng. 7 b01203.

74. Peng X, Kelly RM, Han Y. Sequential processing with fermentative Caldicellulosiruptor kronotskyensis and chemolithoautotrophic Cupriavidus necator for converting rice straw and $\mathrm{CO}_{2}$ to polyhydroxybutyrate. Biotechnol Bioeng. 2018;115:1624-9. https://doi.org/10.1002/bit.26578.

75. Jiang $C$, Cheng Y, Zang H, Chen X, Wang Y, Zhang Y, et al. Biodegradation of lignin and the associated degradation pathway by psychrotrophic Arthrobacter sp. C2 from the cold region of China. Cellulose. 2019;27:1423-40. https://doi.org/10.1007/s10570-019-02858-3.

76. Chan JC, Paice M, Zhang X. Enzymatic oxidation of lignin: challenges and barriers toward practical applications. ChemCatChem. 2019;12:401-25. https://doi.org/10.1002/cctc.201901480.

77. Zhang YH. Production of biofuels and biochemicals by in vitro synthetic biosystems: opportunities and challenges. Biotechnol Adv. 2015;33:1467-83. https://doi.org/10.1016/j.biotechadv.2014.10.009.

78. Piontek K, Antorini M, Choinowski T. Crystal structure of a laccase from the fungus Trametes versicolor at 1.90-Å resolution containing a full complement of coppers. J Biol Chem. 2002;277:37663-9. https://doi. org/10.1074/jbc.M204571200.

79. Bourbonnais R. Oxidation of non-phenolic substrates an expanded role for lactase in lignin biodegradation. FEBS Lett. 1990;267:99-102.

80. Kawal S. Aromatic ring cleavage of 4,6-di(tert-butyl)guaiacol, a phenolic lignin model compound, by lactase of Coriolus versicolor. FEBS Lett. 1988;236:309-11. https://doi.org/10.1016/0014-5793(88)80043-7.

81. Kawai S, Iwatsuki M, Nakagawa M, Inagaki M, Hamabe A, Ohashi H. An alternative $\beta$-ether cleavage pathway for a non-phenolic $\beta$-O-4 lignin model dimer catalyzed by a laccase-mediator system. Enzyme Microb Technol. 2004;35:154-60. https://doi.org/10.1016/j.enzmictec.2004.03. 019.

82. Gutiérrez A, Rencoret J, Cadena EM, Rico A, Barth D, del Río JC, et al. Demonstration of laccase-based removal of lignin from wood and nonwood plant feedstocks. Bioresour Technol. 2012;1 19:114-22. https://doi. org/10.1016/j.biortech.2012.05.112.

83. Thurston CF. The structure and function of fungal laccases. Microbiology. 1994;140:19-26. https://doi.org/10.1099/13500872-140-1-19. 
84. Martinez D, Larrondo LF, Putnam N, Gelpke MD, Huang K, Chapman J, et al. Genome sequence of the lignocellulose degrading fungus Phanerochaete chrysosporium strain RP78. Nat Biotechnol. 2004;22:695-700. https://doi.org/10.1038/nbt967.

85. Poulos TL. Crystallographic refinement of lignin peroxidase at $2 \AA$. J Biol Chem. 1993;268:4429-40.

86. Francesca GM, Lanzalunga O, Lapi A, Piparo MGL, Mancinelli S Isotope-effect profiles in the oxidative $\mathrm{N}$-Demethylation of $\mathrm{N}, \mathrm{N}$ Dimethylanilines catalysed by lignin peroxidase and a chemical model. Eur J Org Chem. 2001;2001:2305-10.

87. Datta R, Kelkar A, Baraniya D, Molaei A, Moulick A, Meena R, et al. Enzymatic degradation of lignin in soil: a review. Sustainability. 2019:9:1163. https://doi.org/10.3390/su9071163.

88. Zhang Z, Xia L, Wang F, Lv P, Zhu M, Li J, et al. Lignin degradation in corn stalk by combined method of $\mathrm{H}_{2} \mathrm{O}_{2}$ hydrolysis and Aspergillus oryzae CGMCC5992 liquid-state fermentation. Biotechnol Biofuels. 2015;8:183. https://doi.org/10.1186/s13068-015-0362-4.

89. Sundaramoorthy M. High-resolution crystal structure of manganese peroxidase: substrate and inhibitor complexes. Biochemistry. 2005:44:6463-70. https://doi.org/10.1021/bi047318e.

90. Hofrichter M. Review: lignin conversion by manganese peroxidase (MnP). Enzyme Microb Technol. 2002;30:454-66. https://doi.org/10. 1016/S0141-0229(01)00528-2.

91. Hildén K, Mäkelä MR, Steffen KT, Hofrichter M, Hatakka A, Archer $\mathrm{DB}$, et al. Biochemical and molecular characterization of an atypical manganese peroxidase of the litter-decomposing fungus Agrocybe praecox. Fungal Genet Biol. 2014;72:131-6. https://doi.org/10.1016/j. fgb.2014.03.002.

92. Jayasinghe PA, Hettiaratchi JP, Mehrotra AK, Kumar S. Effect of enzyme additions on methane production and lignin degradation of landfilled sample of municipal solid waste. Bioresour Technol. 2011;102:4633-7. https://doi.org/10.1016/j.biortech.2011.01.013.

93. Hofrichter M. New and classic families of secreted fungal heme peroxidases. Appl Microbiol Biotechnol. 2010;87:871-97. https://doi. org/10.1007/s00253-010-2633-0.

94. Pérez-Boada M, Ruiz-Duenas FJ, Pogni R, Basosi R, Choinowski T, Martinez $\mathrm{MJ}$, et al. Versatile peroxidase oxidation of high redox potential aromatic compounds: site-directed mutagenesis, spectroscopic and crystallographic investigation of three long-range electron transfer pathways. J Mol Biol. 2005;354:385-402. https://doi.org/10.1016/j. jmb.2005.09.047.

95. Camarero S. Description of a versatile peroxidase involved in the natural degradation of lignin that has both manganese peroxidase and lignin peroxidase substrate interaction sites. J Biol Chem. 1999;274:10324-30. https://doi.org/10.1074/jbc.274.15.10324.

96. Kong W, Fu X, Wang L, Alhujaily A, Zhang J, Ma F, et al. A novel and efficient fungal delignification strategy based on versatile peroxidase for lignocellulose bioconversion. Biotechnol Biofuels. 2017;10:218. https://doi.org/10.1186/s13068-017-0906-x.

97. Mohorcic M, Bencina M, Friedrich J, Jerala R. Expression of soluble versatile peroxidase of Bjerkandera adusta in Escherichia coli. Bioresour Technol. 2009;100:851-8. https://doi.org/10.1016/j.biortech. 2008.07.005.

98. Reiter J, Strittmatter H, Wiemann LO, Schieder D, Sieber V. Enzymatic cleavage of lignin $\beta-\mathrm{O}-4$ aryl ether bonds via net internal hydrogen transfer. Green Chem. 2013;15:1373. https://doi.org/10.1039/c3gc4 0295a.

99. Sato Y, Moriuchi H, Hishiyama S, Otsuka Y, Oshima K, Kasai D, et al. Identification of three alcohol dehydrogenase genes involved in the stereospecific catabolism of arylglycerol- $\beta$-aryl ether by Sphingobium sp. strain SYK-6. Appl Environ Microbiol. 2009;75:5195-201. https:// doi.org/10.1128/AEM.00880-09.

100. Gall DL, Ralph J, Donohue TJ, Noguera DR. A group of sequencerelated sphingomonad enzymes catalyzes cleavage of beta-aryl ether linkages in lignin $\beta$-guaiacyl and $\beta$-syringyl ether dimers. Environ Sci Technol. 2014;48:12454-63. https://doi.org/10.1021/es503886d.

101. Picart P, Muller C, Mottweiler J, Wiermans L, Bolm C, Dominguez de Maria $\mathrm{P}$, et al. From gene towards selective biomass valorization: bacterial $\beta$-etherases with catalytic activity on lignin-like polymers. Chemsuschem. 2014;7:3164-71. https://doi.org/10.1002/cssc.20140 2465.
102. Chio C, Sain M, Qin W. Lignin utilization: a review of lignin depolymerization from various aspects. Renew Sust Energ Rev. 2019;107:232-49. https://doi.org/10.1016/j.rser.2019.03.008.

103. Mnich E, Vanholme R, Oyarce P, Liu S, Lu F, Goeminne G, et al. Degradation of lignin $\beta$-aryl ether units in Arabidopsis thaliana expressing LigD, LigF and LigG from Sphingomonas paucimobilis SYK-6. Plant Biotechnol J. 2017:15:581-93. https://doi.org/10.1111/pbi.12655.

104. Pandey MPK, Kim CS. Lignin depolymerization and conversion: a review of thermochemical methods. Chem Eng Technol. 2011;34:29-41. https://doi.org/10.1002/ceat.201000270.

105. Pieper DH. Aerobic degradation of polychlorinated biphenyls. Appl Microbiol Biotechnol. 2005;67:170-91. https://doi.org/10.1007/ s00253-004-1810-4.

106. Sonoki T. Coexistence of two different $\mathrm{O}$ demethylation systems in lignin metabolism by Sphingomonas paucimobilis SYK-6: cloning and sequencing of the lignin biphenyl-specific O-Demethylase (LigX) gene. Appl Environ Microbiol. 2000;66:2125-32. https://doi.org/10.1128/AEM. 66.5.2125-2132.2000.

107. Peng X. Cloning of a Sphingomonas paucimobilis SYK-6 gene encoding a novel oxygenase that cleaves lignin-related biphenyl and characterization of the enzyme. Appl Environ Microbiol. 1998;64:2520-7.

108. Masai E, Katayama Y, Fukuda M. Genetic and biochemical investigations on bacterial catabolic pathways for lignin-derived aromatic compounds. Biosci Biotechnol Biochem. 2007;71:1-15. https://doi.org/10. $1271 / \mathrm{bbb} .60437$.

109. Li X, Zheng Y. Biotransformation of lignin: mechanisms, applications and future work. Biotechnol Prog. 2020;36:e2922. https://doi.org/10 1002/btpr.2922.

110. Mansfield SD, Kim H, Lu F, Ralph J. Whole plant cell wall characterization using solution-state 2D NMR. Nat Protoc. 2012;7:1579-89. https://doi. org/10.1038/nprot.2012.064.

111. Jiménez $\mathrm{Jl}$. Genomic analysis of the aromatic catabolic pathways from Pseudomonas putida KT2440. Environ Microbiol. 2002;4:824-41. https:// doi.org/10.1046/j.1462-2920.2002.00370.x.

112. Masai E, Harada K, Peng X, Kitayama H, Katayama Y, Fukuda M. Cloning and characterization of the ferulic acid catabolic genes of Sphingomonas paucimobilis SYK-6. Appl Environ Microbiol. 2002;68:4416-24. https://doi.org/10.1128/AEM.68.9.4416-4424.2002.

113. Plaggenborg R, Overhage J, Loos A, Archer JA, Lessard P, Sinskey AJ, et al. Potential of Rhodococcus strains for biotechnological vanillin production from ferulic acid and eugenol. Appl Microbiol Biotechnol. 2006;72:745-55. https://doi.org/10.1007/s00253-005-0302-5.

114. Kasai D, Kamimura N, Tani K, Umeda S, Abe T, Fukuda M, et al. Characterization of FerC, a MarR-type transcriptional regulator, involved in transcriptional regulation of the ferulate catabolic operon in Sphingobium sp. strain SYK-6. FEMS Microbiol Lett. 2012;332:68-75. https://doi. org/10.1111/j.1574-6968.2012.02576.x.

115. Jung DH, Kim EJ, Jung E, Kazlauskas RJ, Choi KY, Kim BG. Production of p-hydroxybenzoic acid from $p$-coumaric acid by Burkholderia glumae BGR1. Biotechnol Bioeng. 2016;113:1493-503. https://doi.org/10.1002/ bit.25908.

116. Fairley DJ, Boyd DR, Sharma ND, Allen CC, Morgan P, Larkin MJ. Aerobic metabolism of 4-hydroxybenzoic acid in Archaea via an unusual pathway involving an intramolecular migration (NIH shift). Appl Environ Microbiol. 2002;68:6246-55. https://doi.org/10.1128/AEM.68.12.62466255.2002.

117. Holesova Z, Jakubkova M, Zavadiakova I, Zeman I, Tomaska L, Nosek J. Gentisate and 3-oxoadipate pathways in the yeast Candida parapsilosis: identification and functional analysis of the genes coding for 3-hydroxybenzoate 6-hydroxylase and 4-hydroxybenzoate 1-hydroxylase. Microbiology. 2011;157:2152-63. https://doi.org/10.1099/mic.0. 048215-0.

118. Xu Z, Lei $P, Z$ Zhai $R$, Wen Z, Jin M. Recent advances in lignin valorization with bacterial cultures: microorganisms, metabolic pathways, and bio-products. Biotechnol Biofuels. 2019;12:32. https://doi.org/10.1186/ s13068-019-1376-0.

119. Graf N. Genetic engineering of Pseudomonas putida KT2440 for rapid and high-yield production of vanillin from ferulic acid. Appl Microbiol Biotechnol. 2014;98:137-49. https://doi.org/10.1007/ s00253-013-5303-1. 
120. Kasai D, Masai E, Miyauchi K, Katayama Y, Fukuda M. Characterization of the 3-O-methylgallate dioxygenase gene and evidence of multiple 3-O-methylgallate catabolic pathways in Sphingomonas paucimobilis SYK-6. J Bacteriol. 2004;186:4951-9. https://doi.org/10.1128/JB.186.15. 4951-4959.2004.

121. Kasai D, Masai E, Miyauchi K, Katayama Y, Fukuda M. Characterization of the gallate dioxygenase gene: three distinct ring cleavage dioxygenases are involved in syringate degradation by Sphingomonas paucimobilis SYK-6. J Bacteriol. 2005;187:5067-74. https://doi.org/10. 1128/JB.187.15.5067-5074.2005.

122. Kasai D, Masai E, Katayama Y, Fukuda M. Degradation of 3-O-methylgallate in Sphingomonas paucimobilis SYK-6 by pathways involving protocatechuate 4,5-dioxygenase. FEMS Microbiol Lett. 2007;274:323-8. https://doi.org/10.1111/j.1574-6968.2007.00855.x.

123. Fuchs $\mathrm{G}$, Boll M, Heider J. Microbial degradation of aromatic compounds_-from one strategy to four. Nat Rev Microbiol. 2011;9:803-16. https://doi.org/10.1038/nrmicro2652.

124. Johnson CWB, Beckham GT. Aromatic catabolic pathway selection for optimal production of pyruvate and lactate from lignin. Metab Eng. 2015;28:240-7. https://doi.org/10.1016/j.ymben.2015.01.005.

125. Liang $\mathrm{MH}$, Jiang JG. Advancing oleaginous microorganisms to produce lipid via metabolic engineering technology. Prog Lipid Res. 2013;52:395-408. https://doi.org/10.1016/j.plipres.2013.05.002.

126. Kosa M, Ragauskas AJ. Bioconversion of lignin model compounds with oleaginous Rhodococci. Appl Microbiol Biotechnol. 2012;93:891-900. https://doi.org/10.1007/s00253-011-3743-z.

127. Shields-Menard SA. The effects of model aromatic lignin compounds on growth and lipid accumulation of Rhodococcus rhodochrous. Int Biodeterior Biodegrad. 2017;121:79-90. https://doi.org/10.1016/j.ibiod. 2017.03.023.

128. Chong GG, Huang XJ, Di JH, Xu DZ, He YC, Pei YN, et al. Biodegradation of alkali lignin by a newly isolated Rhodococcus pyridinivorans CCZUB16. Bioprocess Biosyst Eng. 2018;41:501-10. https://doi.org/10.1007/ s00449-017-1884-x.

129. Wei Z, Zeng G, Huang F, Kosa M, Huang D, Ragauskas AJ. Bioconversion of oxygen-pretreated kraft lignin to microbial lipid with oleaginous Rhodococcus opacus DSM 1069. Green Chem. 2015;17:2784-9. https:// doi.org/10.1039/c5gc00422e.

130. Zhao C, Xie S, Pu Y, Zhang R, Huang F, Ragauskas AJ, et al. Synergistic enzymatic and microbial lignin conversion. Green Chem. 2016;18:130612. https://doi.org/10.1039/c5gc01955a.

131. He Y, Li X, Ben H, Xue X, Yang B. Lipid production from dilute alkali corn stover lignin by Rhodococcus Strains. ACS Sustain Chem Eng. 2017:5:2302-11. https://doi.org/10.1021/acssuschemeng.6b02627.

132. Hu M, Wang J, Gao Q, Bao J. Converting lignin derived phenolic aldehydes into microbial lipid by Trichosporon cutaneum. J Biotechnol. 2018;281:81-6. https://doi.org/10.1016/j.jbiotec.2018.06.341.

133. Ivashechkin AA, Sergeeva YE, Lunin W, Bogdan VI, Mysyakina IS, Feofilova EP. Influence of lignin and oxygen on the growth and the lipid formation of the fungus Lentinus tigrinus. Appl Biochem Microbiol. 2014;50:286-91. https://doi.org/10.1134/S0003683814030089.

134. Poblete-Castro I, Binger D, Rodrigues A, Becker J, Martins Dos Santos VA, Wittmann C. In-silico-driven metabolic engineering of Pseudomonas putida for enhanced production of poly-hydroxyalkanoates. Metab Eng. 2013;15:113-23. https://doi.org/10.1016/j.ymben.2012.10.004.

135. Lettner M, Schöggl J-P, Stern T. Factors influencing the market diffusion of bio-based plastics: results of four comparative scenario analyses. J Clean Prod. 2017;157:289-98. https://doi.org/10.1016/j.jclepro.2017.04. 077.

136. Linger JG, Vardon DR, Guarnieri MT, Karp EM, Hunsinger GB, Franden $M A$, et al. Lignin valorization through integrated biological funneling and chemical catalysis. Proc Natl Acad Sci U S A. 2014;111:12013-8. https://doi.org/10.1073/pnas.1410657111.

137. Numata K, Morisaki K. Screening of marine bacteria to synthesize polyhydroxyalkanoate from lignin: contribution of lignin derivatives to biosynthesis by Oceanimonas doudoroffii. ACS Sustain Chem Eng. 2015;3:569-73. https://doi.org/10.1021/acssuschemeng.5b00031.

138. Shi Y. Characterization and genomic analysis of kraft lignin biodegradation by the beta-proteobacterium Cupriavidus basilensis B-8. Biotechnol Biofuels. 2013;6:1. https://doi.org/10.1186/1754-6834-6-1.
139. Wang X. Simultaneous improvements of Pseudomonas cell growth and polyhydroxyalkanoate production from a lignin derivative for ligninconsolidated bioprocessing. Appl Environ Microbiol. 2018;84:1469. https://doi.org/10.1128/AEM.01469-18.

140. Liu Z-H, Olson ML, Shinde S, Wang X, Hao N, Yoo CG, et al. Synergistic maximization of the carbohydrate output and lignin processability by combinatorial pretreatment. Green Chem. 2017;19:4939-55. https://doi. org/10.1039/c7gc02057k.

141. Ma XK, Daugulis AJ. Effect of bioconversion conditions on vanillin production by Amycolatopsis sp. ATCC 39116 through an analysis of competing by-product formation. Bioprocess Biosyst Eng. 2014;37:8919. https://doi.org/10.1007/s00449-013-1060-x.

142. Sharma RK, Mukhopadhyay D, Gupta P. Microbial fuel cell-mediated lignin depolymerization: a sustainable approach. J Chem Technol Biotechnol. 2019;94:927-32. https://doi.org/10.1002/jctb.5841.

143. Chen P, Yan L, Zhang S, Wu Z, Li S, Yan X, et al. Optimizing bioconversion of ferulic acid to vanillin by Bacillus subtilis in the stirred packed reactor using Box-Behnken design and desirability function. Food Sci Biotechnol. 2017;26:143-52. https://doi.org/10.1007/s10068-017-0019-0.

144. Fleige C, Hansen G, Kroll J, Steinbuchel A. Investigation of the Amycolatopsis sp. strain ATCC 39116 vanillin dehydrogenase and its impact on the biotechnical production of vanillin. Appl Environ Microbiol. 2013;79:81-90. https://doi.org/10.1128/AEM.02358-12.

145. Soni MG, Carabin IG, Burdock GA. Safety assessment of esters of p-hydroxybenzoic acid (parabens). Food Chem Toxicol. 2005;43:9851015. https://doi.org/10.1016/j.fct.2005.01.020.

146. Nemec MJ, Kim H, Marciante AB, Barnes RC, Talcott ST, Mertens-Talcott SU. Pyrogallol, an absorbable microbial gallotannins-metabolite and mango polyphenols (Mangifera Indica L.) suppress breast cancer ductal carcinoma in situ proliferation in vitro. Food Funct. 2016;7:3825-33. https://doi.org/10.1039/c6fo00636a.

147. Curran KA, Leavitt JM, Karim AS, Alper HS. Metabolic engineering of muconic acid production in Saccharomyces cerevisiae. Metab Eng. 2013;15:55-66. https://doi.org/10.1016/j.ymben.2012.10.003.

148. Salvachúa D, Johnson CW, Singer CA, Rohrer H, Peterson DJ, Black BA, et al. Bioprocess development for muconic acid production from aromatic compounds and lignin. Green Chem. 2018;20:5007-19. https:// doi.org/10.1039/c8gc02519c.

149. Kaneko A, Ishii Y, Kirimura K. High-yield production of cis, cis-muconic acid from catechol in aqueous solution by biocatalyst. Chem Lett. 2011;40:381-3. https://doi.org/10.1246/cl.2011.381.

150. Becker J, Wittmann C. A field of dreams: lignin valorization into chemicals, materials, fuels, and health-care products. Biotechnol Adv. 2019;37:107360. https://doi.org/10.1016/j.biotechadv.2019.02.016.

151. Narron $\mathrm{RH}, \mathrm{Kim} \mathrm{H}$, Chang HM, Jameel H, Park S. Biomass pretreatments capable of enabling lignin valorization in a biorefinery process. Curr Opin Biotechnol. 2016;38:39-46. https://doi.org/10.1016/j.copbio.2015. 12.018.

152. Salvachúa D, Katahira R, Cleveland NS, Khanna P, Resch MG, Black BA, et al. Lignin depolymerization by fungal secretomes and a microbial sink. Green Chem. 2016;18:6046-62. https://doi.org/10.1039/c6gc0 $1531 \mathrm{j}$.

153. Kurosawa K, Laser J, Sinskey AJ. Tolerance and adaptive evolution of triacylglycerol-producing Rhodococcus opacus to lignocellulose-derived inhibitors. Biotechnol Biofuels. 2015;8:76. https://doi.org/10.1186/ s13068-015-0258-3.

154. Taniguchi M. Evaluation of pretreatment with Pleurotus ostreatus for enzymatic hydrolysis of rice straw. J Biosci Bioeng. 2005;100:637-43. https://doi.org/10.1263/jbb.100.637.

155. Shirkavand E. Pretreatment of radiata pine using two white rot fungal strains Stereum hirsutum and Trametes versicolor. Energy Convers Manag. 2017;142:13-9. https://doi.org/10.1016/j.enconman.2017.03.021.

156. Dey S. Production of some extracellular enzymes by a lignin peroxidase-producing brown rot fungus, Polyporus ostreiformis, and its comparative abilities for lignin degradation and dye decolorization. Appl Environ Microbiol. 1994;60:4216-8. https://doi.org/10.1128/AEM. 60.11.4216-4218.1994.

157. Mäkelä MR, Bredeweg EL, Magnuson JK, Baker SE, Vries RP, Hildén K. Fungal ligninolytic enzymes and their applications. Microbiol Spectr. 2017;1049-61. https://doi.org/10.1128/microbiolspec.FUNK-0017-2016 
158. Kumar A, Chandra R. Ligninolytic enzymes and its mechanisms for degradation of lignocellulosic waste in environment. Heliyon. 2020;6:e03170. https://doi.org/10.1016/j.heliyon.2020.e03170.

159. Goswami L, Tejas Namboodiri MM, Vinoth Kumar R, Pakshirajan K, Pugazhenthi G. Biodiesel production potential of oleaginous Rhodococcus opacus grown on biomass gasification wastewater. Renew Energ. 2017:105:400-6. https://doi.org/10.1016/j.renene.2016.12.044.

160. Liu ZH, Xie S, Lin F, Jin M, Yuan JS. Combinatorial pretreatment and fermentation optimization enabled a record yield on lignin bioconversion. Biotechnol Biofuels. 2018;11:21. https://doi.org/10.1186/ s13068-018-1021-3.

161. Yu J, Stahl H. Microbial utilization and biopolyester synthesis of bagasse hydrolysates. Bioresour Technol. 2008;99:8042-8. https://doi.org/10. 1016/j.biortech.2008.03.071

162. Prabu CS. Effective utilization and management of coir industrial waste for the production of poly- $\beta$-hydroxybutyrate (PHB) using the bacterium Azotobacter Beijerinickii. Int J Environ Res. 2010;4:519-24.

163. Chattopadhyay P, Banerjee G, Sen SK. Cleaner production of vanillin through biotransformation of ferulic acid esters from agroresidue by
Streptomyces sannanensis. J Clean Prod. 2018;182:272-9. https://doi.org/ 10.1016/j.jclepro.2018.02.043.

164. Kohlstedt M, Starck S, Barton N, Stolzenberger J, Selzer M, Mehlmann K, et al. From lignin to nylon: cascaded chemical and biochemical conversion using metabolically engineered Pseudomonas putida. Metab Eng. 2018;47:279-93. https://doi.org/10.1016/j.ymben.2018.03.003.

165. Sonoki T, Takahashi K, Sugita H, Hatamura M, Azuma Y, Sato T, et al. Glucose-free cis, cis-muconic acid production via new metabolic designs corresponding to the heterogeneity of lignin. ACS Sustain Chem Eng. 2017:6:1256-64. https://doi.org/10.1021/acssuschemeng.7b03597.

\section{Publisher's Note}

Springer Nature remains neutral with regard to jurisdictional claims in published maps and institutional affiliations.
Ready to submit your research? Choose BMC and benefit from:

- fast, convenient online submission

- thorough peer review by experienced researchers in your field

- rapid publication on acceptance

- support for research data, including large and complex data types

- gold Open Access which fosters wider collaboration and increased citations

- maximum visibility for your research: over $100 \mathrm{M}$ website views per year

At BMC, research is always in progress.

Learn more biomedcentral.com/submissions 